\title{
California State Waters Map Series-Hueneme Canyon and Vicinity, California
}

By Samuel Y. Johnson, Peter Dartnell, Guy R. Cochrane, Nadine E. Golden, Eleyne L. Phillips, Andrew C. Ritchie, Rikk G. Kvitek, H. Gary Greene, Lisa M. Krigsman, Charles A. Endris, Kevin B. Clahan, Ray W. Sliter, Florence L. Wong, Mary M. Yoklavich, and William R. Normark

(Samuel Y. Johnson, editor)

Pamphlet to accompany

Scientific Investigations Map 3225

2012

U.S. Department of the Interior

U.S. Geological Survey 


\section{U.S. Department of the Interior \\ KEN SALAZAR, Secretary}

\section{U.S. Geological Survey \\ Marcia K. McNutt, Director}

U.S. Geological Survey, Reston, Virginia: 2012

For more information on the USGS-the Federal source for science about the Earth, its natural and living resources, natural hazards, and the environment-visit

http://www.usgs.gov or call 1-888-ASK-USGS

For an overview of USGS information products, including maps, imagery, and publications, visit http://www.usgs.gov/pubprod

To order this and other USGS information products, visit http://store.usgs.gov

Suggested citation:

Johnson, S.Y., Dartnell, P., Cochrane, G.R., Golden, N.E., Phillips, E.L., Ritchie, A.C., Kvitek, R.G., Greene, H.G., Krigsman, L.M., Endris, C.A., Clahan, K.B., Sliter, R.W., Wong, F.L., Yoklavich, M.M., and Normark, W.R. (S.Y. Johnson, ed.), 2012, California State Waters Map Series-Hueneme Canyon and vicinity, California: U.S. Geological Survey Scientific Investigations Map 3225, 41 p., 12 sheets, available at http://pubs.usgs.gov/sim/3225/.

Any use of trade, product, or firm names is for descriptive purposes only and does not imply endorsement by the U.S. Government.

Although this report is in the public domain, permission must be secured from the individual copyright owners to reproduce any copyrighted material contained within this report. 


\section{Contents}

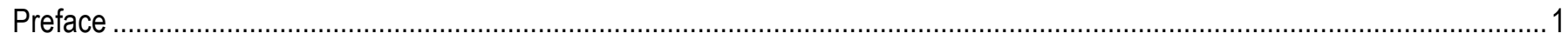

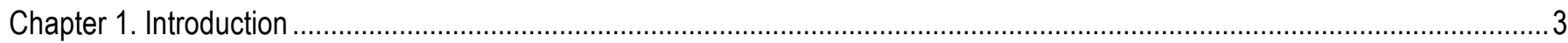

By Samuel Y. Johnson and H. Gary Greene

Chapter 2. Bathymetry and Backscatter-Intensity Maps of Hueneme Canyon and Vicinity (Sheets 1, 2, and 3) .........................7

By Peter Dartnell, Rikk G. Kvitek, and Andrew C. Ritchie

Chapter 3. Data Integration and Visualization for Hueneme Canyon and Vicinity (Sheet 4)

By Peter Dartnell

Chapter 4. Seafloor-Character Map of Hueneme Canyon and Vicinity (Sheet 5)

By Eleyne L. Phillips and Guy R. Cochrane

Chapter 5. Ground-Truth Studies for Hueneme Canyon and Vicinity (Sheet 6)

By Nadine E. Golden and Guy R. Cochrane

Chapter 6. Potential Marine Benthic Habitat Map of Hueneme Canyon and Vicinity (Sheet 7)

By H. Gary Greene and Charles A. Endris

Classifying Potential Marine Benthic Habitats

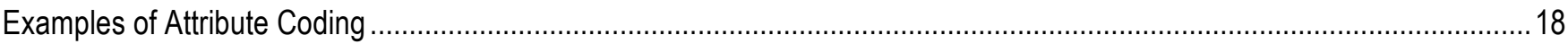

Map Area Habitats....

Chapter 7. Subsurface Geology and Structure of Hueneme Canyon and Vicinity and the Santa Barbara Channel Region

(Sheets 8 and 9)

By Samuel Y. Johnson, Andrew C. Ritchie, Eleyne L. Phillips, Ray W. Sliter, Florence L. Wong, and William R. Normark

Data Acquisition 19

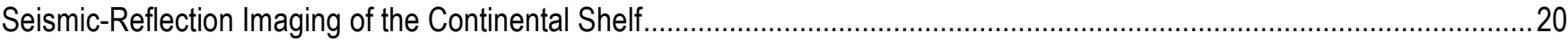

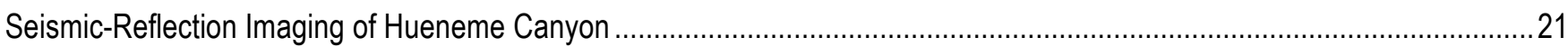

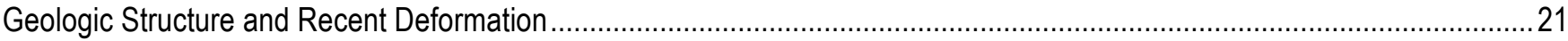

Thickness and Depth to Base of Uppermost Pleistocene and Holocene Deposits ............................................................22

Chapter 8. Geologic and Geomorphic Map of Hueneme Canyon and Vicinity (Sheet 10) and Detailed

Geology/Geomorphology, Slope, and Curvature Maps of Hueneme Canyon (Sheet 11) ..................................................25

By Andrew C. Ritchie and Samuel Y. Johnson

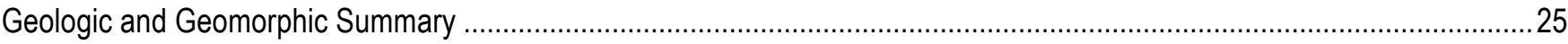

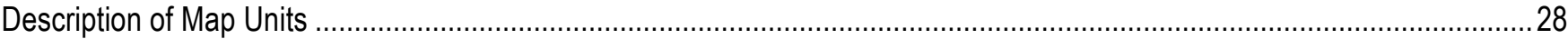

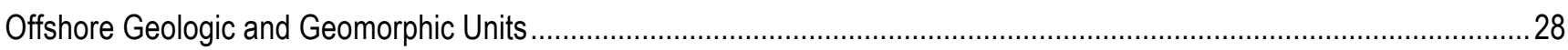

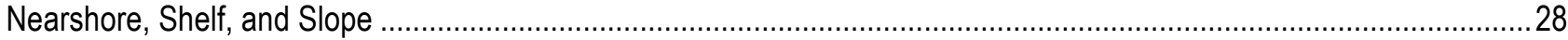

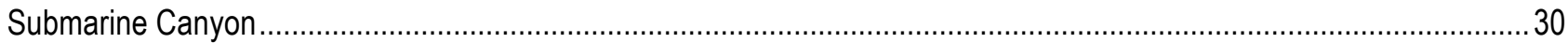

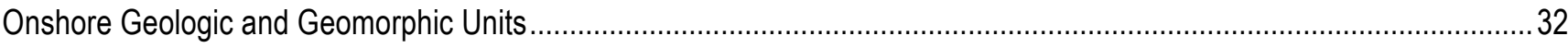

Chapter 9. Predictive Distribution of Benthic Macro-Invertebrates for Hueneme Canyon and Vicinity Map Area and the Santa

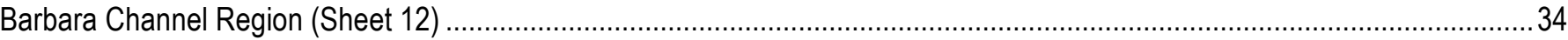

By Lisa M. Krigsman, Mary M. Yoklavich, Nadine E. Golden, and Guy R. Cochrane

References Cited

\section{Figures}

Figure 1-1. Physiography of Santa Barbara Channel region. Box shows Hueneme Canyon and vicinity map area ................4

Figure 1-2. Coastal geography of Hueneme Canyon and vicinity map area...................................................................5 
Figure 4-1. Detailed view of ground-truth data, showing accuracy-assessment methodology.

Figure 5-1. Photograph of camera sled used in USGS 2007 ground-truth survey.....

Figure 5-2. Graph showing distribution of primary and secondary substrate determined from video observations in Hueneme Canyon and vicinity map area.

\section{Tables}

Table 4-1. Accuracy-assessment statistics for seafloor-character-map classifications.

Table 4-2. Conversion table showing how video observations of primary substrate (more than 50 percent seafloor coverage), secondary substrate (more than 20 percent seafloor coverage), and abiotic seafloor complexity (in first three columns) are grouped into seafloor-character-map Classes I, II, and III for use in supervised classification and accuracy assessment.

Table 7-1. Area, sediment-thickness, and sediment-volume data for California's State Waters in Santa Barbara Channel region, between Refugio Beach and Hueneme Canyon areas (domains 1-5), as well as in Hueneme Canyon and vicinity map area and in two areas within map area.

\section{Map Sheets}

Sheet 1. Colored Shaded-Relief Bathymetry, Hueneme Canyon and Vicinity, California

By Rikk G. Kvitek, Eleyne L. Phillips, and Peter Dartnell

Sheet 2. Shaded-Relief Bathymetry, Hueneme Canyon and Vicinity, California

By Rikk G. Kvitek, Eleyne L. Phillips, and Peter Dartnell

Sheet 3. Acoustic Backscatter, Hueneme Canyon and Vicinity, California

By Peter Dartnell, Rikk G. Kvitek, and Eleyne L. Phillips

Sheet 4. Data Integration and Visualization, Hueneme Canyon and Vicinity, California

By Peter Dartnell

Sheet 5. Seafloor Character, Hueneme Canyon and Vicinity, California

By Eleyne L. Phillips and Guy R. Cochrane

Sheet 6. Ground-Truth Studies, Hueneme Canyon and Vicinity, California

By Nadine E. Golden, Guy R. Cochrane, Peter Dartnell, and Lisa M. Krigsman

Sheet 7. Potential Marine Benthic Habitats, Hueneme Canyon and Vicinity, California

By Charles A. Endris, H. Gary Greene, and Nadine E. Golden

Sheet 8. Seismic-Reflection Profiles, Hueneme Canyon and Vicinity, California

By Samuel Y. Johnson, Ray W. Sliter, William R. Normark, and Andrew C. Ritchie

Sheet 9. Local (Hueneme Canyon and Vicinity) and Regional (Offshore Refugio Beach to Hueneme Canyon) ShallowSubsurface Geology and Structure, Santa Barbara Channel, California

By Samuel Y. Johnson, Eleyne L. Phillips, Andrew C. Ritchie, Florence L. Wong, and Ray W. Sliter

Sheet 10. Offshore and Onshore Geology and Geomorphology, Hueneme Canyon and Vicinity, California

By Andrew C. Ritchie, Samuel Y. Johnson, and Kevin B. Clahan

Sheet 11. Detailed Geology and Geomorphology, Hueneme Canyon, California

By Andrew C. Ritchie and Samuel Y. Johnson

Sheet 12. Predicted Distribution of Benthic Macro-Invertebrates, Hueneme Canyon and Vicinity and Santa Barbara Channel Region, California

By Lisa M. Krigsman, Mary M. Yoklavich, Guy R. Cochrane, and Nadine E. Golden 


\section{California State Waters Map Series-Hueneme Canyon and Vicinity, California}

By Samuel Y. Johnson, ${ }^{1}$ Peter Dartnell, ${ }^{1}$ Guy R. Cochrane, ${ }^{1}$ Nadine E. Golden, ${ }^{1}$ Eleyne L. Phillips, ${ }^{1}$ Andrew C. Ritchie, ${ }^{1}$ Rikk G. Kvitek, ${ }^{2}$ H. Gary Greene, ${ }^{3}$ Lisa M. Krigsman, ${ }^{4}$ Charles A. Endris, ${ }^{3}$ Kevin B. Clahan, ${ }^{5}$ Ray W. Sliter, ${ }^{1}$ Florence L. Wong, ${ }^{1}$ Mary M. Yoklavich, ${ }^{4}$ and William R. Normark ${ }^{1}$

(Samuel Y. Johnson, editor)

\section{Preface}

In 2007, the California Ocean Protection Council initiated the California Seafloor Mapping Program (CSMP), designed to create a comprehensive seafloor map of high-resolution bathymetry, marine benthic habitats, and geology within California's State Waters. The program supports a large number of coastal-zone- and ocean-management issues, including the California Marine Life Protection Act (MLPA) (California Department of Fish and Game, 2008), which requires information about the distribution of ecosystems as part of the design and proposal process for the establishment of Marine Protected Areas. A focus of CSMP is to map California's State Waters with consistent methods at a consistent scale.

The CSMP approach is to create highly detailed seafloor maps through collection, integration, interpretation, and visualization of swath sonar data (the undersea equivalent of satellite remote-sensing data in terrestrial mapping), acoustic backscatter, seafloor video, seafloor photography, high-resolution seismic-reflection profiles, and bottom-sediment sampling data. The map products display seafloor morphology and character, identify potential marine benthic habitats, and illustrate both the surficial seafloor geology and shallow (to about $100 \mathrm{~m}$ ) subsurface geology. It is emphasized that the more interpretive habitat and geology maps rely on the integration of multiple, new high-resolution datasets and that mapping at small scales would not be possible without such data.

This approach and CSMP planning is based in part on recommendations of the Marine Mapping Planning Workshop (Kvitek and others, 2006), attended by coastal and marine managers and scientists from around the state. That workshop established geographic priorities for a coastal mapping project and identified the need for coverage of "lands" from the shore strand line (defined as Mean Higher High Water; MHHW) out to the 3-nautical-mile (5.6-km) limit of California's State Waters. Unfortunately, surveying the zone from MHHW out to 10-m water depth is not consistently possible using ship-based surveying methods, owing to sea state (for example, waves, wind, or currents), kelp coverage, and shallow rock outcrops. Accordingly, some of the maps presented in this series commonly do not cover the zone from the shore out to 10-m depth; these "no data" zones appear pale gray on most maps.

This map is part of a series of online U.S. Geological Survey (USGS) publications, each of which includes several map sheets, some explanatory text, and a descriptive pamphlet. Each map sheet

\footnotetext{
${ }^{1}$ U.S. Geological Survey

${ }^{2}$ California State University Monterey Bay, Seafloor Mapping Lab

${ }^{3}$ Moss Landing Marine Laboratories, Center for Habitat Studies

${ }^{4}$ National Oceanic and Atmospheric Administration, National Marine Fisheries Service

${ }^{5}$ California Geological Survey
} 
is published as a PDF file. Geographic information system (GIS) files that contain both ESRI $^{6}$ ArcGIS raster grids (for example, bathymetry, seafloor character) and geotiffs (for example, shaded relief) are also included for each publication. For those who do not own the full suite of ESRI GIS and mapping software, the data can be read using ESRI ArcReader, a free viewer that is available at http://www.esri.com/software/arcgis/arcreader/index.html (last accessed April 5, 2011).

The California Seafloor Mapping Program (CSMP) is a collaborative venture between numerous different federal and state agencies, academia, and the private sector. CSMP partners include the California Coastal Conservancy, the California Ocean Protection Council, the California Department of Fish and Game, the California Geological Survey, California State University at Monterey Bay’s Seafloor Mapping Lab, Moss Landing Marine Laboratories Center for Habitat Studies, Fugro Pelagos, Pacific Gas and Electric Company (PG\&E), National Oceanographic and Atmospheric Administration (NOAA, including National Ocean Service - Office of Coast Surveys, National Marine Sanctuaries, and National Marine Fisheries Service), U.S. Army Corps of Engineers, the Bureau of Ocean Energy Management, the National Park Service, and the U.S. Geological Survey.

\footnotetext{
${ }^{6}$ Environmental Systems Research Institute, Inc.
} 


\title{
Chapter 1. Introduction
}

\author{
By Samuel Y. Johnson and H. Gary Greene
}

The Hueneme Canyon and vicinity map area (figs. 1-1, 1-2) lies within the eastern Santa Barbara Channel region of the Southern California Bight (see, for example, Lee and Normark, 2009). This geologically complex region forms a major biogeographic transition zone, separating the coldtemperate Oregonian province north of Point Conception from the warm-temperate California province to the south (Briggs, 1974).

The map area lies offshore of the Oxnard plain (fig. 1-1), west of and along the trend of the south flank of the Santa Monica Mountains. The Oxnard plain, which is known for its fertile soil and agriculture, represents part of the alluvial plain formed by the Santa Clara River and, to a lesser extent, the Ventura River and Calleguas Creek. Prior to human development, the coastal zone was characterized by a complex of narrow sandy barrier beaches and low dunes interspersed with linear lagoons, marshes, and alluvial flats (Griggs and others, 2005).

The city of Oxnard (population, about 200,000) is the nearest significant onshore cultural center (fig. 1-2). Significant coastal developments include the Port of Hueneme and the Channel Islands Harbor. The Port of Hueneme, completed in 1940, is jointly operated by the United States Navy (Naval Base Ventura County) and the Oxnard Harbor District. The port, protected by long (300-330 m) jetties, is the only deep-water port between Long Beach and San Francisco, and it is the only military deepwater port between San Diego and Washington's Puget Sound. Channel Islands Harbor, which was built as a recreational facility for more than 2,000 boats in the 1960s and 1970s, is protected by two jetties about $400 \mathrm{~m}$ long and an offshore, detached, shore-parallel breakwater about $700 \mathrm{~m}$ long.

The Hueneme Canyon and vicinity map area lies at the east end of the Santa Barbara littoral cell (see, for example, Hapke and others, 2006), which is characterized by west-to-east littoral transport of sediment that is derived mainly from coastal watersheds. For the Hueneme Canyon and vicinity map area, the nearby Santa Clara River is by far the biggest sediment source. This river provides an average of about 3.1 million tons of sediment to the coastal ocean per year, and it is the largest sediment source in all of southern California (Warrick and Farnsworth, 2009a). River discharge and sediment load are highly variable, characterized by brief large events during winter storms and long periods of low flow and minimal sediment load between storms. In recent history, the majority of high-discharge, highsediment-flux events have been associated with El Niño-Southern Oscillation (ENSO) periods (Warrick and Farnsworth, 2009a).

South of the Santa Clara River mouth, sandy beaches are present northwest of Channel Islands Harbor (Hollywood Beach, Oxnard Beach), between Channel Islands Harbor and the Port of Hueneme (Silver Strand), and southeast of the Port of Hueneme (Ormond Beach) (fig. 1-2). Development of the harbor and port has resulted in trapping of some littoral drift, leading to harbor-mouth dredging operations and some coastal erosion (see Griggs and others, 2005). Hapke and others (2006; their fig. 35) suggested that beaches in this area have an accretionary trend over the long term (between the mid1800s and 1998) but have been significantly erosional over the short term (from the mid-1970s to 1998).

The Hueneme Canyon and vicinity map area in California's State Waters is characterized by two major physiographic features: (1) the nearshore continental shelf, and (2) the Hueneme and Mugu Submarine Canyon system, which, in the map area, includes Hueneme Canyon and parts of three smaller, unnamed headless canyons incised into the shelf southeast of Hueneme Canyon. The continental shelf dips very gently (less than $\left.1^{\circ}\right)$, so that, at the 3-nautical-mile $(5.6-\mathrm{km})$ limit of California's State Waters, water depths northwest of Hueneme Canyon are just 20 to $30 \mathrm{~m}$ and, southeast of the canyon, 40 to $50 \mathrm{~m}$. The shelf is relatively narrow in the map area: the shelf break is 


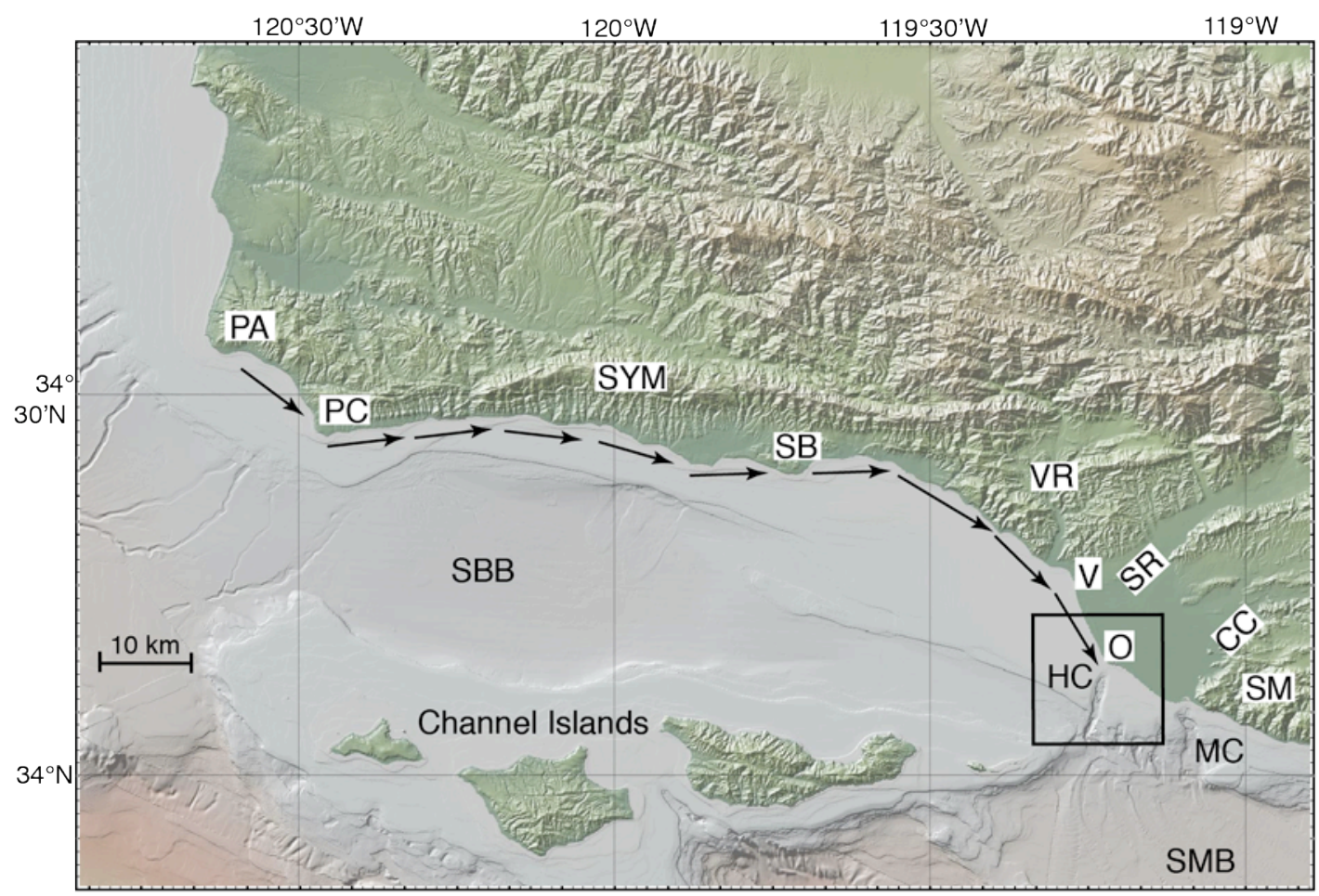

Figure 1-1. Physiography of Santa Barbara Channel region. Box shows Hueneme Canyon and vicinity map area. Arrows show direction of sediment transport in Santa Barbara littoral cell, which extends from Point Arguello (PA) to Hueneme Canyon (HC) and Mugu Canyon (MC). Other abbreviations: CC, Calleguas Creek; O, Oxnard; PC, Point Conception; SB, Santa Barbara; SBB, Santa Barbara Basin; SM, Santa Monica Mountains; SMB, Santa Monica Basin; SR, Santa Clara River; SYM, Santa Ynez Mountains; V, Ventura; VR, Ventura River.

about $7 \mathrm{~km}$ offshore at water depths of about $80 \mathrm{~m}$. This part of the Southern California Bight is relatively well protected from large Pacific north and west swells by Point Conception and the offshore islands and banks (O'Reilly and Guza, 1993); long-period swells affecting the area mainly are from the south-southwest. Fair-weather wave base typically is shallower than 20 -m water depth, but winter storms are capable of resuspending fine-grained sediment in 35 to $70 \mathrm{~m}$ of water (Wiberg and others, 2002; Xu and Noble, 2009), and surficial sediments across this entire section of the shelf probably are mobilized on an annual basis. As with sediment discharge from rivers, the largest wave events and the highest amount of sediment transport on the shelf are thought to be associated with ENSO events. The shelf is underlain by tens of meters of interbedded upper Quaternary shelf, estuarine, and fluvial deposits that formed as sea level fluctuated in the last several hundred thousand years (Dahlen, 1992; Slater and others, 2002).

Hueneme Canyon extends about $15 \mathrm{~km}$ offshore from its canyon head near the dredged navigation channel of the Port of Hueneme. The canyon is relatively deep (about $150 \mathrm{~m}$ at the California's State Waters limit) and steep (canyon flanks as steep as $25^{\circ}$ to $30^{\circ}$ ). Historically, Hueneme Canyon functioned as the eastern termination of the Santa Barbara littoral cell by trapping all eastward littoral drift. In doing so, it not only fed the large Hueneme submarine fan but was the major conduit of sediment to the deep Santa Monica Basin (see, for example, Piper and others, 1999; Normark and others, 2009); however, recent dredging programs, which are needed to maintain Channel Islands Harbor and the Port of Hueneme, have moved the nearshore sediment trapped by jetties and breakwaters to an area southeast of the Hueneme Canyon head. Because of this bypassing, Mugu Canyon, $13 \mathrm{~km}$ to the southeast, now forms the eastern limit of the littoral cell. Other sediment sources to Hueneme Canyon 


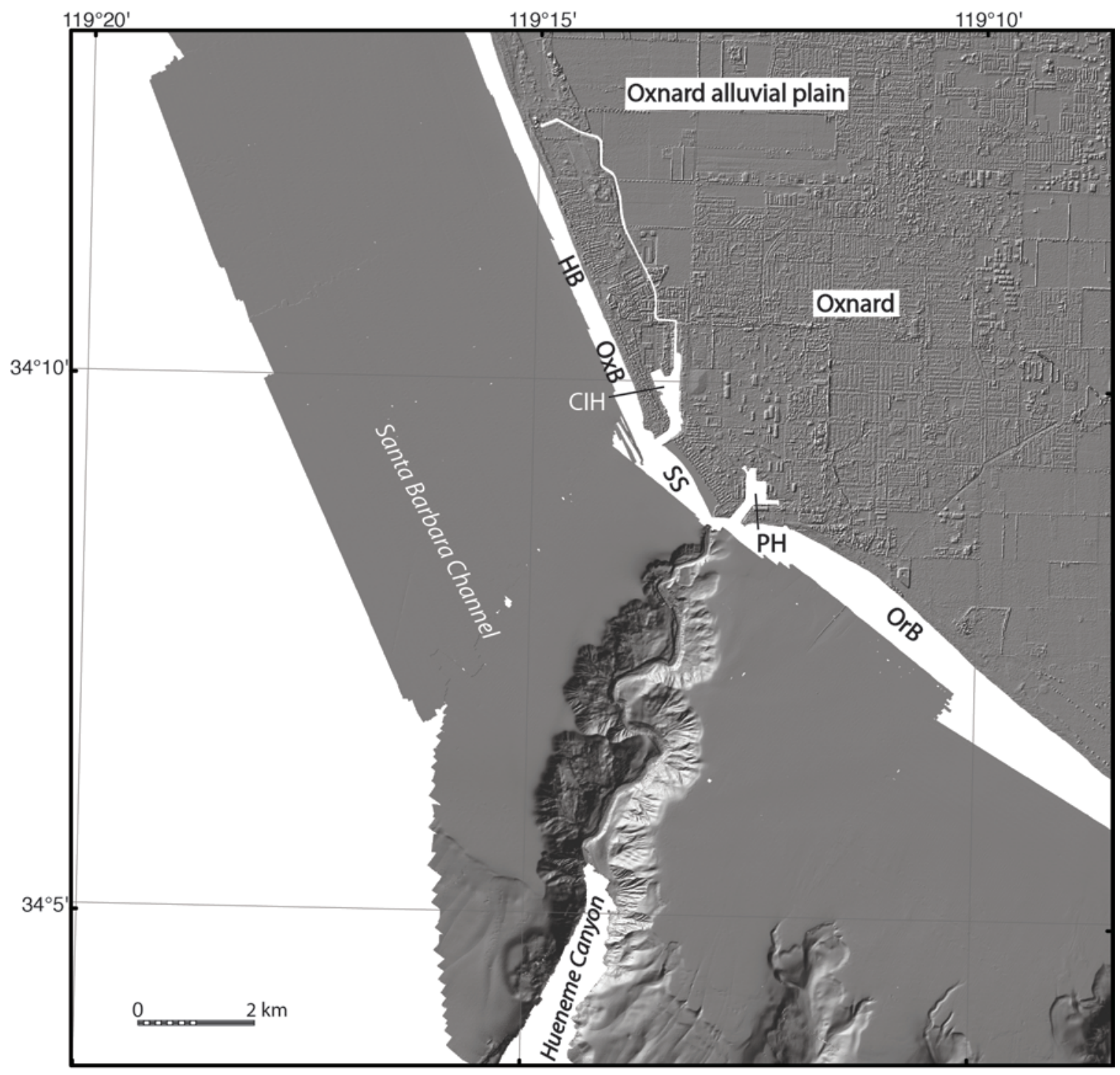

Figure 1-2. Coastal geography of Hueneme Canyon and vicinity map area. Abbreviations: $\mathrm{ClH}$, Channel Islands Harbor; $\mathrm{HB}$, Hollywood Beach; OrB, Ormond Beach; OxB, Oxnard Beach; PH, Port of Hueneme; SS, Silver Strand.

include shelf deposits resuspended and transported eastward during large storms (Xu and others, 2010), landslides from the canyon flanks, and bioaggregates falling from the water column.

The heads of three small unnamed submarine canyons are present in the map area southeast of Hueneme Canyon, but the canyons do not extend into the nearshore zone and, thus, do not receive littoral drift. Their origin is tied to changing sea level, which has risen about $125 \mathrm{~m}$ since the lowstand associated with the Last Glacial Maximum (LGM), about 21,000 years ago (Fairbanks, 1989; Fleming and others, 1998; Lambeck and Chappell, 2001; Lambeck and others, 2002). During the lowstand these canyons were connected to coastal watersheds that fed coarse-grained sediment directly to the deep Santa Monica Basin. During the postglacial transgression, Hueneme Canyon maintained its connection with the shoreline as it eroded headward, whereas these smaller canyons were isolated and abandoned (see, for example, Piper and others, 1999).

Seafloor habitats in the broad Santa Barbara Channel region consist of significant amounts of soft sediment and isolated areas of rocky habitat that support kelp-forest communities nearshore and rocky-reef communities in deep water. The potential marine benthic habitat types mapped in the 
Hueneme Canyon and vicinity area are related directly to the geomorphology and sedimentary processes that are the result of its Quaternary geologic history. Two basic megahabitats are found in the map area, the Shelf (continental shelf) and Flank (continental slope) megahabitats of Greene and others (2007). The Shelf megahabitat is dominated by a flat seafloor and substrates formed from fluvial- and marinesediment deposition during times of changing sea levels, as well as deeply incised submarine canyons. A mud-blanketed slope locally incised with submarine canyons, most of which are inactive and sediment draped, characterizes the Flank megahabitat.

The flat seafloor of the continental shelf in the Hueneme Canyon and vicinity map area is dynamic, as indicated by mobile sand sheets and coarser grained scour depressions. The occurrence of benthic invertebrates is low; however, the low relative relief does provide an irregular seascape that can provide habitat for such fish as juvenile rockfish (Sebastes spp.) and other benthic organisms. The active Hueneme Canyon provides considerable relief to the continental shelf in the map area, and its irregular morphology of eroded walls, landslide scarps, and deposits and gullies provide promising habitat for groundfish, crabs, shrimp, and other marine benthic organisms. Most invertebrates observed in the map area during camera ground-truth field operations are found on the edge of Hueneme Canyon, which may be an important area of recruitment and retention to other invertebrates and fishes. The smaller, more subtle, nonactive headless canyons located primarily on the continental slope also offer relief that provides habitat for groundfish and other organisms.

The map area is part of the Western Transverse Ranges geologic province, which is north of the California Continental Borderland ${ }^{7}$ (Fisher and others, 2009). Significant clockwise rotation—at least $90^{\circ}$ — since the early Miocene has been proposed for the Western Transverse Ranges (Luyendyk and others, 1980; Hornafius and others, 1986; Nicholson and others, 1994), and this region is presently undergoing north-south shortening (see, for example, Larson and Webb, 1992; Donnellan and others, 1993). Shelf deposits are deformed in the northernmost part of the area by the east-west-striking Montalvo Fault and Anticline (Fisher and others, 2005). The Montalvo structures are part of a band of active deformation that includes the east-west-striking Oak Ridge Fault (Huftile and Yeats, 1995; Fisher and others, 2005), which extends offshore just a few kilometers north of the map area. This zone, which forms the southern boundary of the Ventura Basin, is considered an earthquake hazard because it extends along strike for about $130 \mathrm{~km}$ to the east and, thus, appears to be the westward continuation of the fault system responsible for the 1994 M6.7 Northridge earthquake. The area also is undergoing tectonic uplift. Meigs and others (1999) reported that the south and north flanks of the along-strike Santa Monica Mountains are rising $0.5 \pm 0.3 \mathrm{~mm} / \mathrm{yr}$ and $0.24 \pm 0.12 \mathrm{~mm} / \mathrm{yr}$, respectively. In offshore areas, this uplift may be partly offset by subsidence associated with sediment loading.

\footnotetext{
${ }^{7}$ The California Continental Borderland is defined as the complex continental margin extending from Point Conception south into northern Baja California.
} 


\title{
Chapter 2. Bathymetry and Backscatter-Intensity Maps of Hueneme Canyon and Vicinity (Sheets 1, 2, and 3)
}

\author{
By Peter Dartnell, Rikk G. Kvitek, and Andrew C. Ritchie
}

The colored shaded-relief bathymetry (sheet 1), the shaded-relief bathymetry (sheet 2), and the acoustic backscatter (sheet 3) maps of Hueneme Canyon and vicinity in southern California were generated from bathymetry and backscatter data collected by California State University, Monterey Bay (CSUMB); by the U.S. Geological Survey (USGS); and by Fugro Pelagos for the U.S. Army Corps of Engineers (USACE) Joint Lidar Bathymetry Technical Center of Expertise (fig. 1 on sheets 1, 2, 3). Most of the offshore area was mapped by CSUMB in the summers of 2006 and 2007, using a 244-kHz Reson 8101 multibeam echosounder. The far northern part of the offshore area was mapped by the USGS in 2006, using a 117-kHz SEA (AP) Ltd. SWATHplus-M phase-differencing sidescan sonar. The nearshore bathymetry and coastal topography were mapped for USACE by Fugro Pelagos in 2009, using the SHOALS-1000T bathymetric-lidar and Leica ALS60 topographic-lidar systems. All these mapping missions combined to collect bathymetry (sheets 1,2 ) from the 0 -m isobath to beyond the 3-nauticalmile limit of California's State Waters, as well as acoustic-backscatter data (sheet 3) from about the 10$\mathrm{m}$ isobath to beyond the 3-nautical-mile limit.

During the CSUMB mapping missions, an Applanix position and motion compensation system (POS/MV) was used to accurately position the vessel during data collection, and it also accounted for vessel motion such as heave, pitch, and roll (position accuracy, $\pm 2 \mathrm{~m}$; pitch, roll, and heading accuracy, $\pm 0.02^{\circ}$; heave accuracy, $\pm 5 \%$, or $5 \mathrm{~cm}$ ). NavCom 2050 GPS receiver (CNAV) data were used to account for tidal-cycle fluctuations, and sound-velocity profiles were collected with an Applied Microsystems (AM) SVPlus sound velocimeter. Soundings were corrected for vessel motion using the Applanix POS/MV data, for variations in water-column sound velocity using the AM SVPlus data, and for variations in water height (tides) using vertical-position data from the CNAV receiver. Final XYZ soundings and bathymetric-surface models were referenced to the World Geodetic System of 1984 (WGS 1984) relative to the North American Vertical Datum of 1988 (NAVD 1988) (Kvitek, 2007). Backscatter data then were postprocessed using CARIS7.0/Geocoder software. Geobars were created for each survey line using the beam-averaging engine. Intensities were radiometrically corrected (including despeckling and angle-varying gain adjustments), and the position of each acoustic sample was geometrically corrected for slant range on a line-by-line basis. The contrast and brightness of some geobars were adjusted to better match the surrounding geobars. Individual geobars were mosaicked together at 2-m resolution using the auto-seam method. The mosaics were then exported from CARIS as georeferenced TIFF images, imported into a GIS, and converted to GRIDS.

During the USGS mapping mission, GPS data and measurements of vessel motion (heave, pitch, and roll) were combined in a CodaOctopus F180 attitude-and-position system to produce a highprecision vessel-attitude packet. This packet was transmitted to the acquisition software in real time and combined with instantaneous sound-velocity measurements at the transducer head before each ping. The returned samples were projected to the seafloor using a ray-tracing algorithm that works with previously measured sound-velocity profiles. Statistical filters were applied to the raw samples that discriminate the seafloor returns (soundings and backscatter intensity) from unintended targets in the water column. The original soundings were referenced to the WGS 1984 relative to the MLLW (Mean Lower Low Water) tidal datum, but, through postprocessing using NOAA's VDATUM tool, the soundings were transformed to the NAVD 1988. Finally, the soundings were converted into a 2-m-resolution bathymetric-surface model. The backscatter data were postprocessed using USGS software (D.P. Finlayson, 2011, written commun.) that normalizes for time-varying signal loss and beam directivity 
differences. Thus, the raw 16-bit backscatter data were gain-normalized to enhance the backscatter of the SWATHplus system. The resulting normalized-amplitude values were rescaled to 16-bit and gridded into GeoJPEGS using GRID Processor Software, then imported into a GIS and converted to GRIDS.

During the Fugro Pelagos mapping mission that was completed as part of the National Coastal Mapping Program of USACE, the Leica ALS60 topographic-lidar and the SHOALS 1000T bathymetriclidar systems were mounted on an aircraft that flew survey lines at an altitude of 300 to $400 \mathrm{~m}$ (bathymetry) and 300 to 1,200 m (topography), at speeds of between 135 and 185 knots. The ALS60 system collected data at a maximum pulse rate of $200 \mathrm{kHz}$, and the SHOALS system collected data at 1 $\mathrm{kHz}$. Information on aircraft position, velocity, and acceleration were collected using the Novatel and POS A/V 410 systems (SHOALS) and the onboard GPS/IMU system (ALS60). Aircraft-position data were processed using POSPac software, and the results were combined with the lidar data to produce 3D positions for each lidar shot. Various commercial and proprietary software packages were used to clean the data, to convert all valid data from ellipsoid to orthometric heights, and to export the data as a series of topography and bathymetry ASCII files. Final grids were provided in geographic coordinates referenced to the NAVD 1988.

Once all the bathymetric-surface models were transformed to a common projection and datum, the files were merged into one overall 2-m-resolution bathymetric-surface model. Difference calculations of the overlapping bathymetry grids showed that there is good agreement between surveys, even though the surveys were conducted at different times using different mapping equipment. For example, a mean difference of $0.17 \mathrm{~m}$ (0.19 standard deviation) exists between the 2006-2007 CSUMB multibeam-echosounder data and the 2006 USGS SWATHplus data. Also, a mean difference of $0.21 \mathrm{~m}$ (0.26 standard deviation) is present between the CSUMB multibeam-echosounder data and the bathymetric-lidar data, even though the overlap is in the energetic nearshore region that is susceptible to natural change.

An illumination having an azimuth of $300^{\circ}$ and from $45^{\circ}$ above the horizon was then applied to the bathymetric surface to create the shaded-relief imagery (sheets 1,2). In addition, a modified "rainbow" color ramp was applied to the bathymetry data for sheet 1, using reds and oranges to represent shallower depths, and dark blues and purples to represent greater depths. This colored bathymetry surface was draped over the shaded-relief imagery at 60 percent transparency to create a colored shaded-relief map. Bathymetric contours were generated from a modified 10-m-resolution bathymetric surface where a smooth arithmetic mean convolution function applying a weight of oneninth to each cell in a 3-pixel by 3-pixel matrix was applied iteratively to the surface ten times.

Similarly, once all the acoustic-backscatter grids were transformed to a common projection, the grids were combined in a geographic information system (GIS) to create an acoustic-backscatter map (sheet 3), on which brighter tones indicate higher backscatter intensity, and darker tones indicate lower backscatter intensity. The intensity represents a complex interaction between the acoustic pulse and the seafloor, as well as characteristics within the shallow subsurface, providing a general indication of seafloor texture and sediment type. Backscatter intensity depends on the acoustic source level; the frequency used to image the seafloor; the grazing angle; the composition and character of the seafloor, including grain size, water content, bulk density, and seafloor roughness; and some biological cover. Harder and rougher bottom types such as rocky outcrops or coarse sediment typically return stronger intensities (high backscatter, lighter tones), whereas softer bottom types such as fine sediment return weaker intensities (low backscatter, darker tones).

The onshore-area image was generated by applying an illumination having an azimuth of $300^{\circ}$ and from $45^{\circ}$ above the horizon to the topographic-lidar data, as well as to publicly available, 3-mresolution, interferometric synthetic aperture radar (ifSAR) data, available from NOAA Coastal Service Center's Digital Coast (National Oceanic and Atmospheric Administration, 2011). 


\title{
Chapter 3. Data Integration and Visualization for Hueneme Canyon and Vicinity (Sheet 4)
}

\author{
By Peter Dartnell
}

Mapping California's State Waters has produced a vast amount of acoustic and visual data, including bathymetry, acoustic backscatter, seismic-reflection profiles, and seafloor video and photography. These data are used by researchers to develop maps, reports, and other tools to assist in the coastal and marine spatial-planning capability of coastal-zone managers and other stakeholders. For example, seafloor-character (sheet 5), habitat (sheet 7), and geologic (sheets 10,11) maps of Hueneme Canyon and vicinity are used to assist in the designation of Marine Protected Areas, as well as in their monitoring. These maps and reports also help to analyze environmental change owing to sea-level rise and coastal development, to model and predict sediment and contaminant budgets and transport, to site offshore infrastructure, and to assess tsunami and earthquake hazards. To facilitate this increased understanding and to assist product development, it is helpful to integrate the different datasets and then view the results in three-dimensional representations such as those displayed on the data integration and visualization sheet for Hueneme Canyon and vicinity (sheet 4 ).

The maps and three-dimensional views on sheet 4 were created using a series of geographic information systems (GIS) and visualization techniques. Using GIS, the bathymetric and topographic data (sheet 1) were converted to ASCIIRASTER format files, and the acoustic-backscatter data (sheet 3) were converted to geoTIFF images. The bathymetric and topographic data were imported in the Fledermaus ${ }^{\circledR}$ software (QPS). The bathymetry was color-coded to closely match the colored shadedrelief bathymetry on sheet 1 in which reds and oranges represent shallower depths and dark blues and purples represent deeper depths. Topographic data were shown in gray shades. The acoustic-backscatter geoTIFF images were also draped over the bathymetry data. The colored bathymetry, topography, and draped backscatter were then draped, tilted, and panned to create the perspective views such as those shown in figures 1, 2, 5, and 6 on sheet 4 . These figures highlight the scale and morphology of Hueneme Canyon, the structure and slope of the channel axis, the incision of canyon flanks, and the presence of landslide scarps and deposits.

Video-mosaic images created from digital seafloor video (for example, fig. 4 on sheet 4) display the geologic complexity (rock, sand, and mud; see sheet 10) and biologic complexity (see sheet 12) of the seafloor. Whereas photographs capture high-quality snapshots of smaller areas of the seafloor (see sheet 6), video mosaics capture larger areas and can show transition zones between seafloor environments. Digital seafloor video is collected from a camera sled towed approximately 1 to 2 meters over the seafloor, at speeds less than 1 nautical mile/hour. Using standard video-editing software, as well as software developed at the Center for Coastal and Ocean Mapping, University of New Hampshire, the digital video is converted to AVI format, cut into 2-minute sections, and desampled to every 2nd or 3rd frame. The frames are merged together using pattern-recognition algorithms from one frame to the next and converted to a TIFF image. The images are then rectified to the bathymetry data using ship navigation recorded with the video and layback estimates.

Block diagrams that combine the bathymetry with seismic-profile data help integrate surface and subsurface observations, especially stratigraphic and structural relationships (for example, fig. 6 on sheet 4). These block diagrams were created by converting digital seismic-profile data into TIFF images (Sliter and others, 2008), while taking note of the starting and ending coordinates and maximum and minimum depths. The images were then imported into the Fledermaus ${ }^{\circledR}$ software as vertical images and merged with the bathymetry imagery. 


\title{
Chapter 4. Seafloor-Character Map of Hueneme Canyon and Vicinity (Sheet 5)
}

\author{
By Eleyne L. Phillips and Guy R. Cochrane
}

The California State Marine Life Protection Act (MLPA) calls for protecting representative types of habitat in different depth zones and environmental conditions. A science team, assembled under the auspices of the California Department of Fish and Game (CDFG), has identified seven substrate-defined seafloor habitats in California's State Waters that can be classified using sonar data and seafloor video and photography. These habitats include rocky banks, intertidal zones, sandy or soft ocean bottoms, underwater pinnacles, kelp forests, submarine canyons, and seagrass beds. The following five depth zones, which determine changes in species composition, are identified: Depth Zone 1, intertidal; Depth Zone 2, intertidal to $30 \mathrm{~m}$; Depth Zone 3, 30 to $100 \mathrm{~m}$; Depth Zone 4, 100 to $200 \mathrm{~m}$; and Depth Zone 5, deeper than $200 \mathrm{~m}$ (California Department of Fish and Game, 2008). The CDFG habitats, with the exception of depth zones, can be considered a subset of a broader classification scheme of Greene and others (1999) that has been used by the U.S. Geological Survey (USGS) (Cochrane and others, 2003, 2005). These seafloor-character maps are generalized polygon shape files that have attributes derived from Greene and others (2007).

A 2007 Coastal Map Development Workshop, hosted by the USGS in Menlo Park, California, identified the need for more detailed (relative to Greene and others' [1999] attributes) raster products that preserve some of the transitional character of the seafloor when substrates are mixed and (or) change gradationally. The seafloor-character map (sheet 5), which delineates a subset of the CDFG habitats, is a GIS-derived raster product that can be produced in a consistent manner from data of variable quality covering large geographic regions.

The following three substrate classes are identified:

- Class I: Fine- to medium-grained smooth sediment

- Class II: Mixed smooth sediment and rock

- Class III: Rock and boulder, rugose

The seafloor-character map was produced using video-supervised maximum likelihood classification of the bathymetry and intensity of return from sonar systems, following the method described by Cochrane (2008). The two variants used in this classification were backscatter intensity and derivative rugosity, which is a standard calculation performed with the NOAA benthic-terrain modeler (available at http://www.csc.noaa.gov/digitalcoast/tools/btm/index.html; last accessed April 5, 2011), using a 3-pixel by 3-pixel array of bathymetry.

On the seafloor-character map (sheet 5), the three substrate classes have been colored to indicate the California MLPA depth zone and the Coastal and Marine Ecological Classification Standard (CMECS) slope zone (Madden and others, 2008) in which they belong. The California MLPA depth zones are Depth Zone 1 (intertidal), Depth Zone 2 (intertidal to $30 \mathrm{~m}$ ), Depth Zone 3 (30 to $100 \mathrm{~m}$ ), Depth Zone 4 (100 to $200 \mathrm{~m}$ ), and Depth Zone 5 (greater than $200 \mathrm{~m}$ ). The slope classes used on this map represent the following CMECS slope zones: Slope Class $1=$ flat $\left(0^{\circ}\right.$ to $\left.5^{\circ}\right)$; Slope Class $2=$ sloping $\left(5^{\circ}\right.$ to $\left.30^{\circ}\right)$; Slope Class $3=$ steeply sloping $\left(30^{\circ}\right.$ to $\left.60^{\circ}\right)$; Slope Class $4=\operatorname{vertical}\left(60^{\circ}\right.$ to $\left.90^{\circ}\right)$; and Slope Class $5=$ overhang (greater than $90^{\circ}$ ). The final classified seafloor-character raster map image is draped over the shaded-relief bathymetry for the area (sheets 1 and 2) to produce the image shown on the seafloor-character map.

The seafloor-character classification is also summarized on sheet 5 in table 1. Fine- to mediumgrained smooth sediment makes up 99.0 percent $\left(139.8 \mathrm{~km}^{2}\right)$ of the region: $83.5 \mathrm{~km}^{2}$ in Depth Zone 2, $34.9 \mathrm{~km}^{2}$ in Depth Zone 3, $12.0 \mathrm{~km}^{2}$ in Depth Zone 4, and $9.5 \mathrm{~km}^{2}$ in Depth Zone 5. Mixed smooth 
Table 4-1. Accuracy-assessment statistics for seafloor-character-map classifications.

[Accuracy assessments are based on video observations (N/A, no accuracy assessment was conducted)]

\begin{tabular}{|l|c|c|c|}
\hline \multicolumn{1}{|c|}{ Class } & $\begin{array}{c}\text { Number of } \\
\text { observations }\end{array}$ & $\%$ majority & \% presence/absence \\
\hline I—-Fine- to medium grained smooth sediment & 478 & 99.7 & 100.0 \\
\hline II-Mixed smooth sediment and rock & 1 & N/A & N/A \\
\hline III-Rock and boulder, rugose & 0 & N/A & N/A \\
\hline
\end{tabular}

sediment and rock (sediment that typically forms a veneer over bedrock, or rock outcrops with little to no relief) make up 1.0 percent $\left(1.5 \mathrm{~km}^{2}\right)$ of the area mapped: $0.1 \mathrm{~km}^{2}$ in Depth Zone 2, $0.5 \mathrm{~km}^{2}$ in Depth Zone 3, $0.4 \mathrm{~km}^{2}$ in Depth Zone 4, and $0.5 \mathrm{~km}^{2}$ in Depth Zone 5. Rock and boulder, or rugose (rock and boulder fields with high surficial complexity), make up less than 0.1 percent $\left(<0.1 \mathrm{~km}^{2}\right)$ of the region, and it is present only in Depth Zone 2. Anthropogenic material (for example, a pipe) makes up less than 0.1 percent $\left(<0.1 \mathrm{~km}^{2}\right)$ of the region, and it is present only in Depth Zone 2 .

A few video observations are used to check the classification of the seafloor. All video observations (see sheet 6) are used for accuracy assessment of the seafloor-character map after classification. To compare observations to classified pixels, each observation point is assigned a class (I, II, or III), according to the visually derived, major or minor geologic component (for example, sand or rock) and the abiotic complexity (vertical variability) of the substrate (tables 4-1, 4-2). Next, circular buffer areas are created around individual observation points using a 10-m radius to account for layback and positional inaccuracies inherent to the towed-camera system. The radius length is an average of the distances between the positions of sharp interfaces seen on both the video (the position of the ship at the time of observation) and sonar data, plus the distance covered during a 10-second observation period at

Table 4-2. Conversion table showing how video observations of primary substrate (more than 50 percent seafloor coverage), secondary substrate (more than 20 percent seafloor coverage), and abiotic seafloor complexity (in first three columns) are grouped into seafloorcharacter-map Classes I, II, and III for use in supervised classification and accuracy assessment.

[In areas of low visibility where primary and secondary substrate could not be identified with confidence, recorded observations of substrate (in fourth column) were used to assess accuracy]

\begin{tabular}{|c|c|c|c|}
\hline Primary-substrate component & Secondary-substrate component & $\begin{array}{c}\text { Abiotic seafloor } \\
\text { complexity }\end{array}$ & $\begin{array}{l}\text { Low-visibility } \\
\text { observations }\end{array}$ \\
\hline \multicolumn{4}{|c|}{ Class I } \\
\hline mud & mud & low & \\
\hline mud & sand & low & \\
\hline sand & gravel & low & \\
\hline sand & mud & low & \\
\hline \multirow[t]{3}{*}{ sand } & sand & low & \\
\hline & & & sediments \\
\hline & & & ripples \\
\hline
\end{tabular}


an average speed of 1 nautical mile/hour. Each buffer, which covers more than $300 \mathrm{~m}^{2}$, contains approximately 77 pixels. The classified (I, II, III) buffer is used as a mask to extract pixels from the seafloor-character map. These pixels are then compared to the class of the buffer. For example, if the shipboard-video observation is Class II (mixed smooth sediment and rock), but 12 of the 77 pixels within the buffer area are characterized as Class I (fine- to medium-grained smooth sediment), and 15 (of the 77) are characterized as Class III (rock and boulder, rugose), then the comparison would be "Class I, 12; Class II, 50; Class III, 15" (fig. 4-1). If the video observation of substrate is Class II, then the classification is accurate because the majority of seafloor pixels in the buffer are Class II. The accuracy numbers in table 4-1 represent the final of several classification iterations aimed at achieving the best accuracy, given the variable quality of sonar data (see discussion in Cochrane, 2008) and the limited ground-truth information available when compared to the continuous coverage provided by swath sonar.

The seafloor in the Hueneme Canyon and vicinity map area predominantly is Class I sediments composed of sand and mud. Only one video observation of Class II seafloor, and no video observations of Class III seafloor, were made in the area. Areas of Class II substrate in the map area were classified on the basis of observations of Class II seafloor on multibeam data that extended outside of the map area. No accuracy assessment was done for Class II or III.
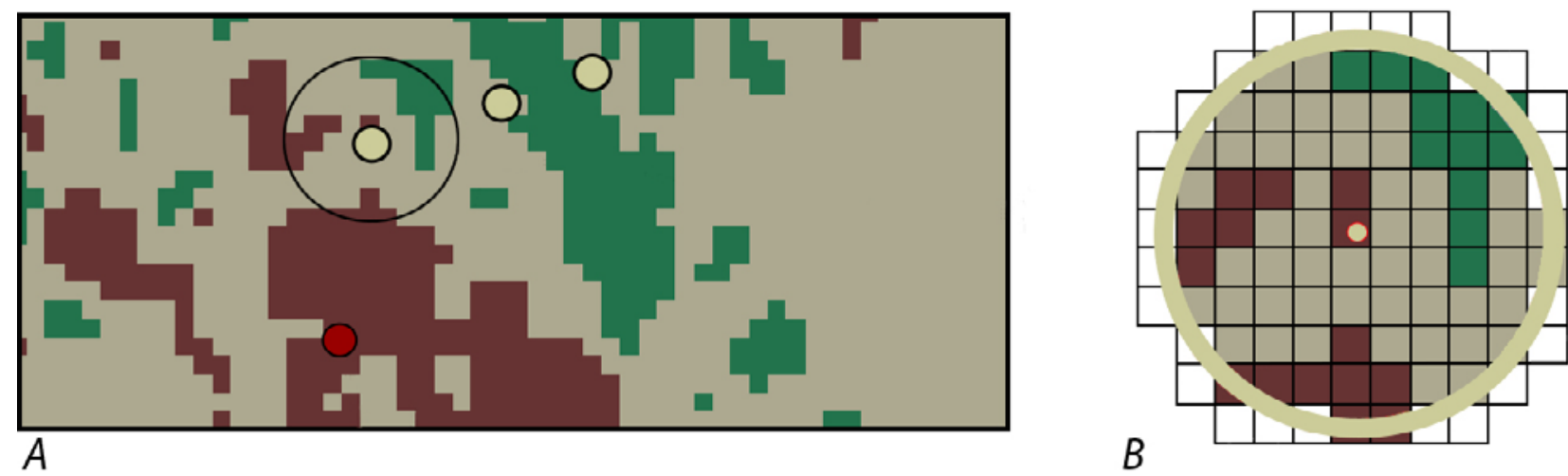

Figure 4-1. Detailed view of ground-truth data, showing accuracy-assessment methodology. $A$, Dots illustrate ground-truth observation points, each of which represents 10-second window of substrate observation plotted over seafloor-character grid; circle around dot illustrates area of buffer depicted in $B$. B. Pixels of seafloor-character data within 10-m-radius buffer centered on one individual ground-truth video observation. 


\title{
Chapter 5. Ground-Truth Studies for Hueneme Canyon and Vicinity (Sheet 6)
}

\author{
By Nadine E. Golden and Guy R. Cochrane
}

To validate the interpretations of sonar data in order to turn it into geologically and biologically useful information, the U.S. Geological Survey (USGS) towed a camera sled (fig. 5-1) over specific locations throughout the Hueneme Canyon and vicinity map area to collect video and photographic data that would "ground truth" the seafloor. This ground-truth surveying occurred on two separate cruises in 2007 and 2008. The camera sled was towed 1 to $2 \mathrm{~m}$ over the seafloor at speeds of between 1 and 2 nautical miles/hour. Ground-truth surveys in this map area include approximately 18.39 trackline kilometers of video and 479 still photographs, in addition to 545 recorded seafloor observations of abiotic and biotic attributes. A visual estimate of slope also was recorded.

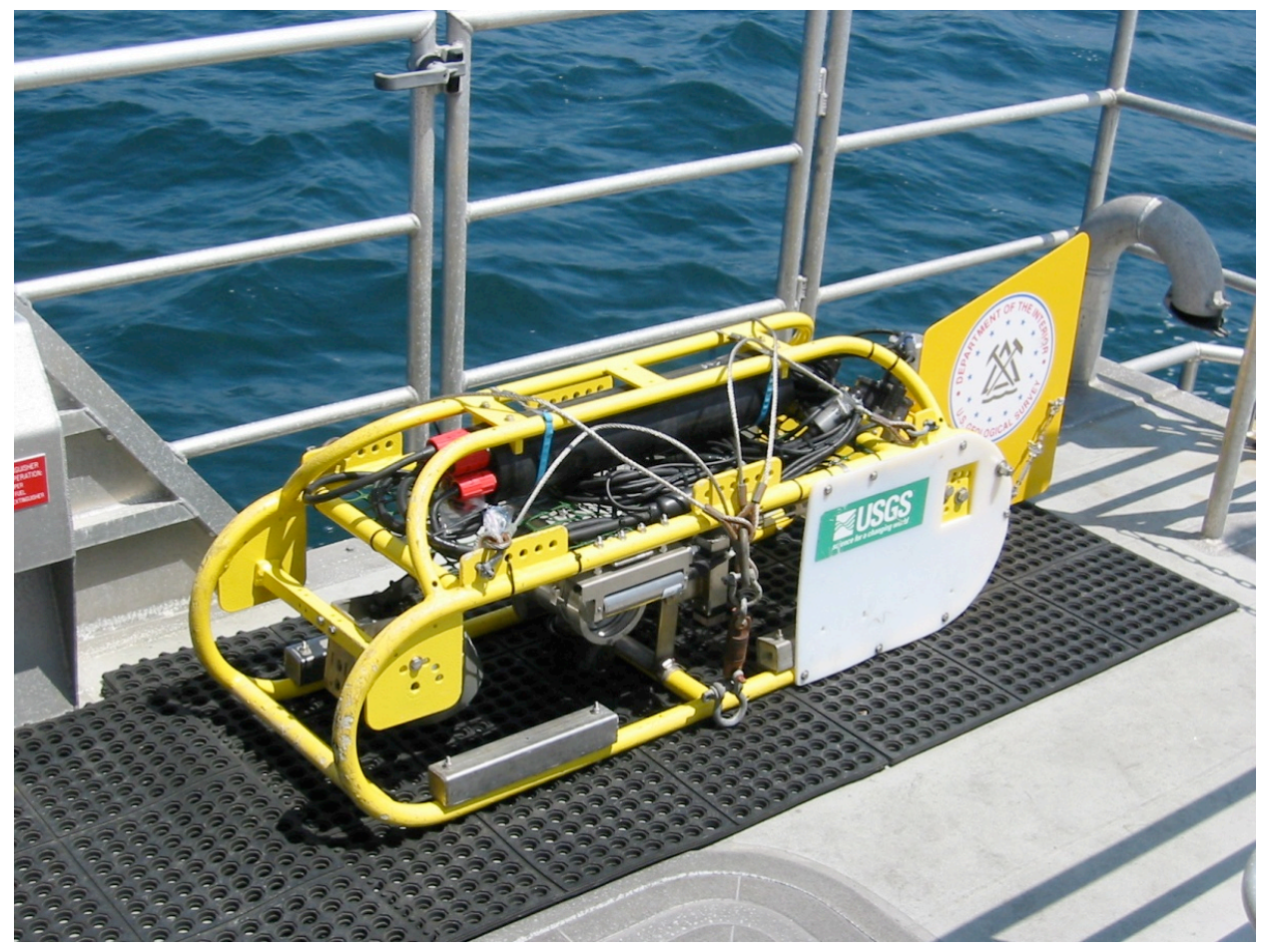

Figure 5-1. Photograph of camera sled used in USGS 2007 ground-truth survey.

During the 2007 cruise, the USGS camera sled housed two video cameras: one was forward looking, and the other was downward looking. During the 2008 cruise, a larger camera sled was used that housed two video cameras (one forward looking and one downward looking), a high-definition video camera, and an 8-megapixel digital still camera. During this cruise, in addition to recording the seafloor characteristics, a digital still photograph was captured once every 30 seconds.

The camera-sled tracklines (shown by colored circles on the map on sheet 6) are sited in order to visually inspect areas representative of the full range of bottom hardness and rugosity in the map area. The video is fed to the research vessel in real time, where USGS and NOAA scientists record both the geologic and biologic character of the seafloor. While the camera is deployed, several different observations are recorded for a 10-second period once every minute, using the protocol of Anderson and others (2007). 
Primary and secondary substrates constitute greater than 50 and 20 percent of the seafloor, respectively, during an observation. The classifications are based on the Wentworth scale, except that the granule and pebble sizes have been grouped together into a class called "gravel," and the clay and silt sizes have been grouped together into a class called "mud." Benthic-habitat complexity, which is divided into abiotic (geologic) and biotic (biologic) components, refers to the visual classification of local geologic features and biota that potentially can provide refuge for both juvenile and adult forms of various species (Tissot and others, 2006).

Sheet 6 contains a smaller, generalized version of the seafloor-character map on sheet 5 (derived by removing depth-zone symbology), in addition to the colored camera-sled tracklines used to groundtruth-survey the sonar data. Only the abiotic attributes are used in the production of the seafloorcharacter map (sheet 5); of these abiotic attributes, two components (primary and secondary substrate composition) are shown as a series of colored dots. Also shown are locations of the detailed subregions; for each subregion, a box (boxes A through E on sheet 6) contains representative seafloor photographs and an explanation of the observed seafloor characteristics recorded by USGS and NOAA scientists. Individual photographs often show more substrate types than are reported as the primary and secondary substrate. Organisms, when present, are labeled on the photographs.

The ground-truth survey is designed to investigate areas of multibeam bathymetry and backscatter-intensity variation. Figure 5-2 shows that, in this map area, very little backscatter-intensity variation is the result of changes in substrate. Only two observations of seafloor substrate were of a material other than sand or mud.

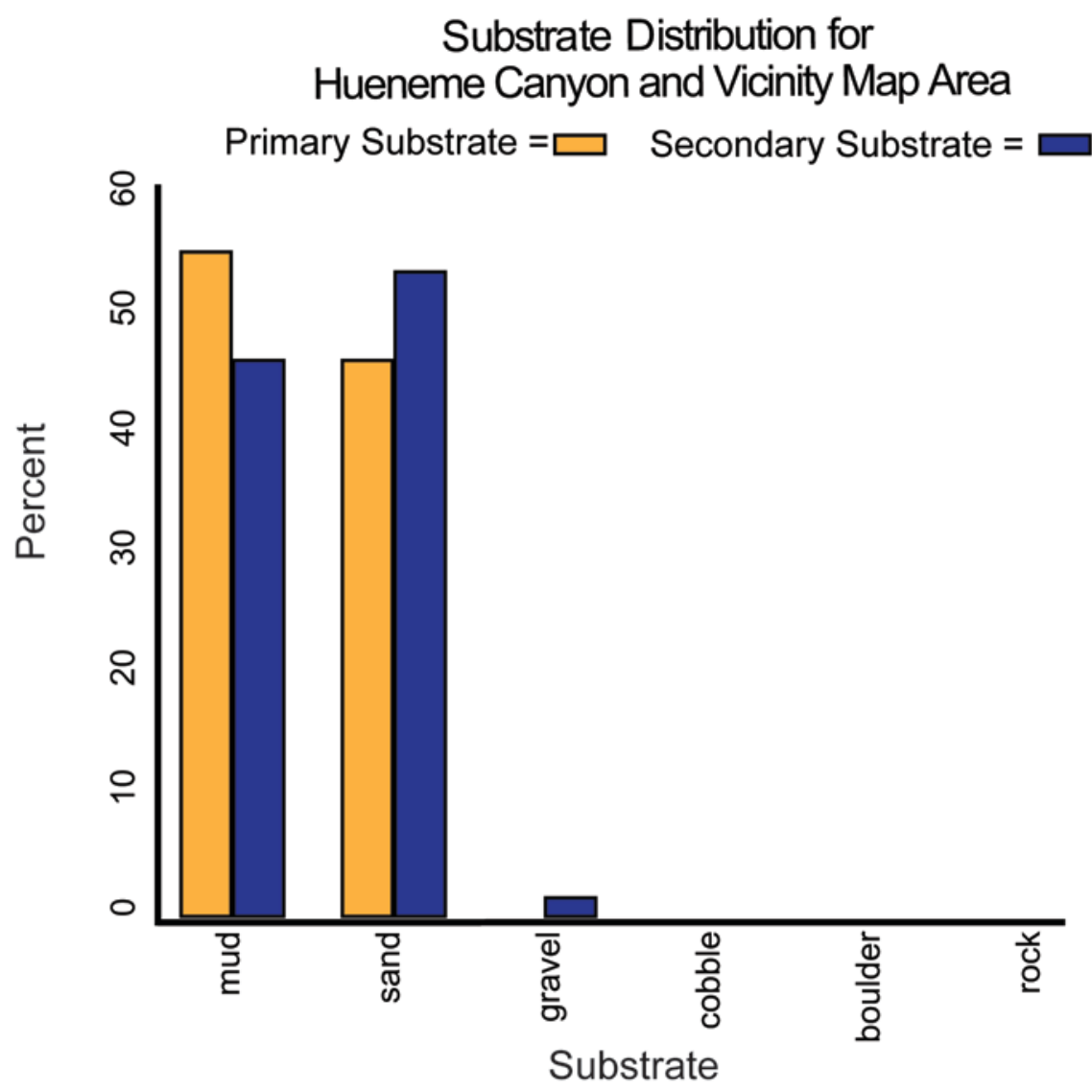

Figure 5-2. Graph showing distribution of primary and secondary substrate determined from video observations in Hueneme Canyon and vicinity map area. 


\title{
Chapter 6. Potential Marine Benthic Habitat Map of Hueneme Canyon and Vicinity (Sheet 7)
}

\author{
By H. Gary Greene and Charles A. Endris
}

The map on sheet 7 shows "potential" marine benthic habitats of Hueneme Canyon and vicinity, representing a substrate type, geomorphology, seafloor process, or any other attribute that may provide a habitat for a specific species or assemblage of organisms. This map, which is based largely on seafloor geology, also integrates information displayed on several other thematic maps of Hueneme Canyon and vicinity. High-resolution sonar bathymetry data, converted to depth grids (seafloor DEMs; sheets 1, 2), are essential to development of the potential marine benthic habitat map, as is shaded-relief imagery (sheet 4), which allows visualization of seafloor terrain and provides a foundation for interpretation of submarine landforms.

Backscatter maps (sheet 3) are also essential for developing potential benthic habitat maps. High backscatter is further indication of "hard" bottom, consistent with interpretation as rock or coarse sediment. Low backscatter, indicative of a "soft" bottom, generally indicates a fine sediment environment. Habitat interpretations are also informed by actual seafloor observations from ground-truth surveying (sheet 6), by seafloor-character maps that are based on video-supervised maximum-likelihood classification (sheet 5), and by seafloor-geology maps (sheets 10,11). The habitat interpretations on sheet 7 are further informed by the usSEABED bottom-sampling compilation of Reid and others (2006).

Broad, generally smooth areas of seafloor that lack sharp and angular edge characteristics are mapped as "sediment;" these areas may be further defined by various sedimentary features (for example, erosional scours and depressions) and (or) depositional features (for example, dunes, mounds, or sand waves). In contrast, many areas of seafloor bedrock exposures are identified by their common sharp edges and high relative relief; these may be contiguous outcrops, isolated parts of outcrop protruding through sediment cover (pinnacles or knobs), or isolated boulders. In many locations, areas within or around a rocky feature appear to be covered by a thin veneer of sediment; these areas are identified on the habitat map as "mixed" induration (that is, containing both rock and sediment). The combination of remotely observed data (for example, high-resolution bathymetry and backscatter, seismic-reflection profiles) and directly observed data (for example, camera transects, sediment samples) translates to higher confidence in the ability to interpret broad areas of the seafloor.

To avoid any possible misunderstanding of the term "habitat," the term "potential habitat" (as defined by Greene and others, 2005) is used herein to describe a set of distinct seafloor conditions that in the future may qualify as an "actual habitat." Once habitat associations of a species are determined, they can be used to create maps that depict actual habitats, which then need to be confirmed by in situ observations, video, and (or) photographic documentation.

\section{Classifying Potential Marine Benthic Habitats}

Potential marine benthic habitats in the Hueneme Canyon and vicinity are mapped using the Benthic Marine Potential Habitat Classification Scheme, a mapping-attribute code developed by Greene and others $(1999,2007)$. This code, which has been used previously in other offshore California areas (see, for example, Greene and others, 2005, 2007), was developed to easily create categories of marine benthic habitats that can then be queried within a GIS or a database. The code contains several categories that can be subdivided relative to the spatial scale of the data. The following categories can be applied directly to habitat interpretations determined from remote-sensing imagery collected at a scale of tens of kilometers to one meter: Megahabitat, Seafloor Induration, Meso/Macrohabitat, Modifier, 
Seafloor Slope, Seafloor Complexity, and Geologic Unit. Additional categories of Macro/Microhabitat, Seafloor Slope, and Seafloor Complexity can be applied to habitat interpretations determined from seafloor samples, video, still photographs, or direct observations at a scale of 10 meters to a few centimeters. These two scale-dependent groups of categories can be used together, to define a habitat across spatial scales, or separately, to compare large- and small-scale habitat types.

The five categories and their attribute codes that are used on the Hueneme Canyon map are explained in detail below (note, however, that not all categories may be used in a particular area, given the study objectives, data availability, or data quality); attribute codes in each category are depicted on the map by the letters and, in some cases, numbers that make up the map-unit symbols:

Megahabitat - Based on depth and general physiographic boundaries; used to distinguish features on a scale of tens of kilometers to kilometers. Depicted on map by capital letter, listed first in map-unit symbol; generalized depth ranges are given below.

$\mathrm{F}=\quad$ Flank; continental slope, basin and (or) island flanks (200 to $3,000 \mathrm{~m}$ )

$S=\quad$ Shelf; continental and island shelves (0 to $200 \mathrm{~m})$

Seafloor Induration - Refers to substrate hardness. Depicted on map by lower-case letter, listed second in map-unit symbol; may be further subdivided into distinct sediment types, depicted by lowercase letter(s) in parentheses, listed immediately after substrate hardness; multiple attributes listed in general order of relative abundance, separated by slash; queried where inferred.

$\mathrm{h}=\quad$ Hard bottom (for example, rock outcrop or sediment pavement)

$\mathrm{m}=\quad$ Mixed hard and soft bottom (for example, local sediment cover of bedrock)

$\mathbf{s}=\quad$ Soft bottom; sediment cover

$(\mathrm{g})=$ Gravel

$(\mathrm{s})=$ Sand

$(m)=$ Mud, silt, and (or) clay

Meso/Macrohabitat - Related to scale of habitat; consists of seafloor features one kilometer to one meter in size. Depicted on map by lower-case letter and, in some cases, additional lower-case letter in parentheses, listed third in map-unit symbol; multiple attributes separated by slash.

$b=\quad$ Beach, relic (submerged) or shoreline

$(\mathrm{b}) / \mathrm{p}=$ Pinnacle indistinguishable from boulder

$\mathrm{c}=$ Canyon

$c(b)=$ Bar within thalweg

$c(c)=$ Curve or meander within thalweg

$c(f)=$ Fall or chute within thalweg

$\mathrm{c}(\mathrm{h})=$ Canyon head

$\mathrm{c}(\mathrm{m})=$ Canyon mouth

$\mathrm{c}(\mathrm{t})=\quad$ Thalweg

$\mathrm{c}(\mathrm{w})=$ Canyon wall

$\mathrm{d}=\quad$ Deformed, tilted and (or) folded bedrock; overhang

$\mathrm{e}=\quad$ Exposure; bedrock

$\mathrm{f}=\quad$ Flat; floor

$\mathrm{g}=\quad$ Gully; channel

$\mathrm{h}=$ Hole; depression

$\mathrm{I}=\quad$ Landslide; mass movement; rubble

$\mathrm{m}=\quad$ Mound; linear ridge

$\mathrm{o}=\quad$ Overbank deposit; levee

$\mathrm{p}=\quad$ Pinnacle; cone

$r=\quad$ Rill (linear depression on surface formed by subterranean winnowing of sediment)

$\mathbf{S}=\quad$ Scarp, cliff, fault, or slump scar 


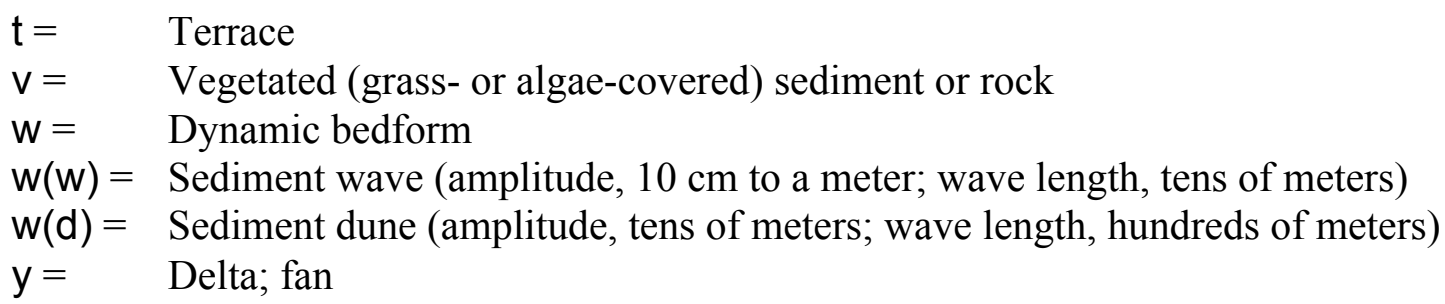

Modifier-Describes texture, bedforms, biology, or lithology of seafloor. Depicted on map by lower-case letter following an underscore; multiple attributes separated by slash.

${ }^{a}=$ Anthropogenic (artificial reef, breakwall, shipwreck, disturbance)

a-c $=\quad$ Cable

a-dd $=$ Dredge disturbance

a-dg $=$ Dredge groove or channel

-a-dp $=$ Dredge potholes

-a-dm $=$ Dredge mound (disposal)

a-dp $=$ Dredge pothole

_a-f $=\quad$ Ferry (or other vessel) propeller-wash scour or scar

a-g $=\quad$ Groin, jetty, rip-rap

_a-m = Marina, harbor

a-p $=$ Pipeline

_a-s $=\quad$ Support; dock piling, dolphin

-a-td $=$ Trawl disturbance

-a-w = Wreck, ship, barge, or plane

$\mathrm{b}=\quad$ Bimodal (conglomeratic, mixed [gravel, cobbles, and pebbles])

conglomerate)

c $=$ Consolidated sediment (claystone, mudstone, siltstone, sandstone, breccia, or

- $d=\quad$ Differentially eroded

e $=$ Effusive pit; pockmark

$-\mathrm{f}=$ Fracture, joint; faulted

$\mathrm{g}=$ Granite

$\mathrm{h}=$ Hummocky, irregular relief

$-{ }_{\mathbf{i}}=\quad$ Interface; lithologic contact

$-\mathrm{k}=$ Kelp

- $m=$ Massive sedimentary bedrock

$\mathrm{O}=$ Outwash

- $p=$ Pavement

_r $=\quad$ Ripple (amplitude, greater than $10 \mathrm{~cm}$ )

$-\mathrm{s}=\quad$ Scour (current or ice; direction noted)

$-\mathrm{u}=\quad$ Unconsolidated sediment

$-\mathrm{v}=\quad$ Volcanic rock

$\mathrm{w}=$ Wall

Seafloor Slope - Denotes slope, typically calculated from XYZ high-resolution bathymetry data. Depicted on map by number, listed after modifier.

$1=\quad$ Flat $\left(0^{\circ}-5^{\circ}\right)$

$2=\quad$ Sloping $\left(5^{\circ}-30^{\circ}\right)$

$3=\quad$ Steeply sloping $\left(30^{\circ}-45^{\circ}\right)$

$4=\quad$ Vertical or near vertical $\left(45^{\circ}-90^{\circ}\right)$

$5=\quad$ Overhanging (more than $90^{\circ}$ )

$6=$ Unknown 


\section{Examples of Attribute Coding}

To illustrate how these attribute codes can be used to describe remotely sensed data, the following examples are given:

Ssc(h)_u2/4 = Canyon head that indents shelf and has smooth, soft, gently sloping, sedimentary walls, locally cropping out as steep (near vertical) scarps (10 to $100 \mathrm{~m}$ ).

Ssf_u1 = Flat to gently sloping shelf that has soft, unconsolidated sediment (10 to $150 \mathrm{~m}$ ).

Fhe_m/c $=$ Continental slope that has hard sedimentary (sandstone) bedrock exposures locally and smooth to moderately irregular relief (less than $1 \mathrm{~m}$ to $3 \mathrm{~m}$ high); exposures often covered with sediment (200 to $2,500 \mathrm{~m})$.

\section{Map Area Habitats}

The Hueneme Canyon and vicinity map area includes the western part of the Hueneme-Mugu Canyon system (Greene and others, 1978), which includes Hueneme Canyon and the heads of three smaller canyons on its east flank. The areas between the canyons consist of gently offshore-sloping continental-shelf habitats. Delineated on the map area are 29 potential marine benthic habitat types: 21 are found on, or incised into, the continental shelf ("Shelf" megahabitat), and 8 are identified on the continental slope ("Flank" megahabitat). The meso- and macrohabitats include canyon walls, scarps, channels (thalwegs), gullies, and terraces, as well as dynamic features such as landslides and channel bars within the canyons; they also include rills, pockmarks, depressions, mobile sand sheets, and anthropogenic features on the flat continental shelf. Backscatter data show that most of the area is underlain by "soft" materials, consistent with the interpretation that unconsolidated sediments dominate habitat in the map area.

Although much of the map area is flat and appears fairly homogeneous, sedimentary processes are quite active and, thus, habitats are highly dynamic. Sediment transport is primarily to the southeast. In addition, erosion through shelf sediments down to a coarser lag has produced "ripple scour depressions" (see, for example, Cacchione and others, 1984) on the shelf in the northwestern part of the map area.

The head of Hueneme Canyon is virtually at the shoreline, and it intercepts large volumes of sediment that are being transported southeastward in the littoral zone and on the shelf. Thus, Hueneme Canyon serves as the main conduit for moving sediment from the Santa Barbara littoral cell offshore into the deep Santa Monica Basin (Greene and others, 1978; Normark and others, 2009; Romans and others, 2009). Within the canyon, lateral sediment derived from the shelf incises canyon walls and accumulates on midwall locations that are prone to landslides. Sediment entering the canyon from the shelf and its nearshore head moves rapidly downcanyon in turbidity currents (Xu and others, 2010), forming bars and dunes on the canyon floor and commonly undercutting canyon walls, further promoting landslides. Habitats, therefore, are created, modified, destroyed, and recreated regularly in this dynamic environment.

Of the $138.1 \mathrm{~km}^{2}$ in the map area, $128.3 \mathrm{~km}^{2}$ (92.9 percent) is classified as Shelf megahabitat, and $9.8 \mathrm{~km}^{2}$ (7.1 percent) is classified as Flank (slope) megahabitat; although most of the Shelf megahabitat is flat and homogeneous, $3.2 \mathrm{~km}^{2}$ (2.4 percent of the map area) consists of ripple scour depressions. Landslide scarps and landslide deposits, which are found in both Shelf and Flank megahabitats, cover $1.3 \mathrm{~km}^{2}$ (0.9 percent) and $5.7 \mathrm{~km}^{2}$ (4.1 percent) of the map area, respectively. The thalweg habitat, which is restricted to Hueneme Canyon, covers $1.5 \mathrm{~km}^{2}(1.1$ percent $)$ of the map area. 


\title{
Chapter 7. Subsurface Geology and Structure of Hueneme Canyon and Vicinity and the Santa Barbara Channel Region (Sheets 8 and 9)
}

\author{
By Samuel Y. Johnson, Andrew C. Ritchie, Eleyne L. Phillips, Ray W. Sliter, Florence L. Wong, and William R. \\ Normark
}

The seismic-reflection profiles presented on sheet 8 provide a third dimension, depth, to complement the surficial seafloor-mapping data already presented (sheets 1-7) for the Hueneme Canyon and vicinity. These data, which are collected at several resolutions, extend to varying depths in the subsurface, depending on the purpose and mode of data acquisition. The seismic-reflection profiles provide information on sediment character, distribution, and thickness, as well as potential geologic hazards, including active faults, areas prone to strong ground motion, and tsunamigenic slope failures. The information on faults provides essential input to national and state earthquake-hazard maps and assessments (for example, Petersen and others, 2008).

Sheet 9 shows the following interpretations, which are based on the seismic-reflection profiles on sheet 8: the thickness of the uppermost sediment unit; the depth to base of this uppermost unit; and both the local and regional distribution of faults and earthquake epicenters (data from Heck, 1998; Minor and others, 2009; Jennings and Bryant, 2010; Southern California Earthquake Data Center, 2010).

\section{Data Acquisition}

Most profiles on sheet 8 (figs. 1, 2B, 3, 4, 5, 6, 7, 8, and 10) were collected in 2007 on USGS cruise Z-3-07-SC (Sliter and others, 2008). Single-channel seismic-reflection data were acquired using the SIG 2Mille, 50-tip, minisparker. The SIG minisparker system used a 500-J high-voltage electrical discharge fired 1 to 4 times per second, which, at normal survey speed of 4 to 4.5 nautical miles/hour, gives a data trace every 0.5 to $2.0 \mathrm{~m}$ of lateral distance covered. The data were digitally recorded in standard SEG-Y 32-bit floating-point format, using Triton Subbottom Logger (SBL) software that merges seismic-reflection data with differential GPS-navigation data. After the survey, a short-window (20 milliseconds) automatic gain control algorithm and a 160- to 1,200-Hz bandpass filter was applied to the data. The maximum subbottom penetration of this minisparker system is about $200 \mathrm{~m}$.

Data for the profile in figure $2 A$ (sheet 8) were collected in 2002 on USGS cruise A-1-02-SC (Sliter and others, 2008). This profile was obtained using the 500-J sparker from a Huntec deep-tow fish as the source and a single-channel, surface-towed streamer as the receiver. The source was towed at a minimum depth of about $5 \mathrm{~m}$, well below boat-propeller wash. The sparker produced an effective frequency range of 1 to $6 \mathrm{kHz}$, with peak power at about $1 \mathrm{kHz}$. The data were recorded by a Delph recording system using a sampling frequency of $16 \mathrm{kHz}$.

Figure 9 (sheet 8) shows a deep-penetration, migrated, multichannel seismic-reflection profile collected in 1981 by WesternGeco on cruise W-23-81-SC. This profile and other similar data were collected in many areas offshore California in the 1970s and 1980s when the area was considered a frontier for oil and gas exploration. Much of these data have been publicly released and are now archived at the U.S. Geological Survey National Archive of Marine Seismic Surveys (U.S. Geological Survey, 2009). These data were acquired using a large-volume air-gun source at a frequency range of 3 to $40 \mathrm{~Hz}$ and recorded with a multichannel hydrophone streamer about $2 \mathrm{~km}$ long. Shot spacing was about $30 \mathrm{~m}$. These data can resolve geologic features that are 20 to $30 \mathrm{~m}$ thick to subbottom depths of about $4 \mathrm{~km}$. 


\section{Seismic-Reflection Imaging of the Continental Shelf}

The Hueneme Canyon and vicinity map area lies offshore of the large alluvial plain of the Santa Clara and Ventura Rivers and Calleguas Creek (fig. 1-1), and its dominant physiographic features are the continental shelf and Hueneme Canyon (see sheets 1,2). These drainages provide the largest sediment fluxes in southern California (Warrick and Farnsworth, 2009a). Many investigations (see, for example, Dahlen, 1992; Slater and others, 2002; Sommerfield and others, 2009) have suggested that the shelf is underlain by thick Pleistocene and Holocene sediments mainly derived from these two large fluvial systems. Sommerfield and others (2009) estimated that the eastern Santa Barbara shelf contains $12 \mathrm{~km}^{3}$ of sediment, a volume equal to one-third of the total amount of postglacial (that is, younger than about 21,000 years old) sediment on the greater southern California shelf; they further suggested that, during the latest stages of glaciation and early deglaciation, Santa Clara River discharge may have been an order of magnitude larger than present levels.

Sea level has risen about $125 \mathrm{~m}$ in the last about 21,000 years following the Last Glacial Maximum (Fairbanks, 1989; Fleming and others, 1998; Lambeck and Chappell, 2001; Lambeck and others, 2002). The rise was rapid, about 9 to 11 meters per thousand years, until about 7,000 years ago when it slowed considerably to about 1 meter per thousand years. On the high-resolution profiles, sediments deposited during this latest Pleistocene and Holocene sea-level rise (blue-shaded unit on sheet 8; thicknesses shown on sheet 9) typically are characterized by parallel, low- to moderate-amplitude, moderate- to high-frequency, continuous to moderately continuous reflections (terminology from Mitchum and others, 1977). An upward decrease in reflection amplitude is seen on many profiles.

The lower part of the latest Pleistocene and Holocene sequence (blue-shaded unit on sheet 8) most likely includes a transition from marginal-marine to nearshore and shelf sediments, which occurred as sea level rose and the shoreline migrated both landward and upward. The upper part of these deposits probably consists of shelf sediments similar to those being deposited on the shelf today (see sheet 6). Sea-level rise, which also includes the effects of tectonic land-level change, was apparently not steady during deposition, leading to development of pairs of shoreline angles and adjacent submerged wave-cut platforms (Kern, 1977) that typically are buried by shelf sediment (see, for example, fig. 10 on sheet 8); However, the original morphology of four paired shoreline angles and wave-cut platforms is at least partly preserved at the shelf break on the east flank of Hueneme Canyon (see sheets 10, 11).

Because deposition in this area apparently was continuous from before the Last Glacial Maximum (LGM) to after the LGM, the base of the post-LGM deposits (blue-shaded unit on sheet 8) is not as clearly defined here as in many other parts of offshore California. To the north in the Monterey Bay area, for example, these deposits commonly are acoustically transparent on seismic-reflection profiles, and they are bounded at their base by high-amplitude reflection(s) (see, for example, Chin and others, 1988; Anima and others, 2002; Grossman and others, 2006). Elsewhere (for example, to the west in the Santa Barbara Channel; Draut and others, 2009), the sediments are deposited with obvious angular unconformity on a prominent wave-cut platform of hard bedrock.

In the Hueneme Canyon and vicinity map area, the post-LGM deposits are recognized by the following combination of factors: (1) the differences in seismic-facies characteristics between lowstand alluvial and estuarine deposits and transgressive marine deposits; (2) the identification and mapping of a stratigraphic horizon at the base of buried channels (see, for example, figs. 5, 6, and 10 on sheet 8), which are inferred to have cut through transgressive shelf deposits down to lowstand deposits during sea-level rise (similar to the methods of Dahlen, 1992); (3) the comparison with similar mapping of the stratigraphic horizon of the deepest preserved shoreline angle at the shelf break (about $120 \mathrm{~m}$ deep; see sheets 10,11), the assumed base level at the end of the LGM; and (4) the offshore extrapolation of deposit thicknesses from the Holocene isopach map of Greene and others (1978, their plate 7), the contours of which are constrained by coastal well logs. By tracing this horizon across the network of 
adjacent seismic profiles, values were determined for unit thickness and depth to the base of the unit that were then contoured to produce the thickness and depth-to-base maps on sheet 9.

Redin and Kamerling (2004) prepared a detailed, north-trending, geologic cross section of the area north of Hueneme Canyon; the section is subparallel to, and just offshore of, the 3-nautical-mile limit of California's State Waters. The cross section, which is based on deep-penetration, industryacquired seismic-reflection data and logs of nine petroleum-exploration wells (as deep as 5,400 m) indicates that the postglacial sedimentary unit is underlain by about $600 \mathrm{~m}$ of undivided sediments of the Pliocene and Pleistocene Santa Barbara and Saugus Formations.

\section{Seismic-Reflection Imaging of Hueneme Canyon}

The head of Hueneme Canyon is in the nearshore zone, and the canyon bisects the entire continental shelf, serving as a major conduit of sediment to deep offshore basins. Major geologic and geomorphic components within the canyon include canyon walls, landslide scarps and deposits, and both axial- and lateral-canyon fill. Canyon walls, which are locally as steep as $50^{\circ}$, form at the shelf edge, at intermediate depths within the canyon, and deep within the canyon, bounding the canyon's axial channel. Sonar mapping reveals gradations in canyon walls from deeply incised to smooth and draped with a thin sediment cover. Canyon walls on the east edge of the canyon typically are more incised than those on the western canyon edge. The thin sediment cover on canyon walls commonly blends with the seafloor reflection and, thus, is not clearly imaged on the seismic-reflection profiles.

Landslide deposits, which are present locally beneath the floor of the canyon (commonly below axial-channel fill; see figs. 6, 7 on sheet 8) and also perched on channel flanks (see fig. 7 on sheet 8), are internally characterized by discontinuous, hummocky to chaotic, low- to moderate-amplitude, lowfrequency reflections and diffractions.

Axial-channel fill is present along the canyon floor, forming variably incised, downcanyondipping surfaces that are as wide as $850 \mathrm{~m}$ across the channel (see fig. 7 on sheet 8). On seismicreflection profiles, this facies consists of moderately continuous to continuous, parallel to divergent, moderate-amplitude, high-frequency reflections that commonly appear to onlap and (or) drape underlying irregular surfaces (for example, landslide deposits). Lateral-canyon fill, which is present near the mouth of the canyon on its east flank, is imaged by moderately continuous, parallel to divergent, moderate-amplitude, high-frequency reflections that dip toward the channel axis. This lateral-canyon fill, which is inferred to have graded into axial-channel fill, is distinguished by its steeper (as much as $7^{\circ}$ ) cross-canyon dips. This facies is distinguished from perched landslides by its continuous, parallel to divergent, high-frequency internal reflections.

\section{Geologic Structure and Recent Deformation}

The Montalvo Fault and Anticline system (Yeats and others, 1988; Fisher and others, 2005) is the most prominent tectonic feature in the map area; figure $2 A$ on sheet 8 shows truncation, offset, and warping of reflections within the youngest (latest Pleistocene and Holocene) stratigraphic unit by this system. Folding reveals as much as $4 \mathrm{~m}$ of uplift (up to the southeast) along a steep fault within about 12 $\mathrm{m}$ of the seafloor. Other seismic profiles that cross the Montalvo Fault and Anticline at a high angle show shallow faulting but no significant vertical displacement (see, for example, figs. $2 B, 3$ on sheet 8), and no significant change in sediment thickness is seen across this structure (sheet 9). The local, variable character of shallow-fault-related deformation is consistent with interpretations of Fisher and others (2005), who suggested that this structure dips steeply and has mainly lateral (sinistral) slip.

The Montalvo Fault and Anticline are part of a band of active deformation that includes the eastwest-striking Oak Ridge Fault (Yeats and others, 1988; Yeats and Huftile, 1995), which extends offshore just a few kilometers north of the map area. The Oak Ridge Fault, which forms the southern 
boundary of the Ventura Basin, is considered an earthquake hazard because it extends along strike for about $130 \mathrm{~km}$ and appears to be the westward continuation of the fault system responsible for the 1994 M 6.7 Northridge earthquake. Other important east-west-striking structures in the northern Santa Barbara Channel include the Pitas Point Fault and the Red Mountain Fault Zone (Sorlien and others, 2000; Fisher and others, 2009).

A northeast-striking set of faults extends for about $6 \mathrm{~km}$ along the west flank of Hueneme Canyon. Offsets on a few shallow, high-resolution seismic-reflection profiles (for example, fig. 4 on sheet 8) extend upward into the post-LGM deposits (blue-shaded unit on sheet 8). These structures are probably within the zone of northeast-striking structures mapped by Heck (1998), and they may be the ones shown on the cross section of Redin and Kamerling (2004) and also may be along the strike of a transfer zone suggested by Shaw and Suppe (1994). A few short, east-west-striking faults are mapped on seismic-reflection profiles east of Hueneme Canyon. In addition, seismic-reflection profiles (see figures 9, 10 on sheet 8) show significant folding in the southeastern part of the map area (outside the 3nautical-mile limit of California's State Waters). It is not clear whether these folds deform the postLGM deposits (blue-shaded unit on sheet 8); rather, this deformation may coincide with the late Tertiary and Quaternary folding that underlies the angular unconformity highlighted by dashed-green lines on figures $1,2,3,5,6$, and 8 on sheet 8 .

The regional pattern of faults and earthquakes occurring between 1932 and 2010 that have inferred or measured magnitudes greater than 2.0 are shown on Map C (sheet 9). Although locations have been provided by the CalTech network since 1932, significantly greater precision began in 1969 with installation of a USGS seismographic network (see, for example, Lee and Vedder, 1973; Sylvester, 2001; Southern California Earthquake Data Center, 2010). Epicentral data indicate that seismicity in the eastern and central Santa Barbara Channel is characterized by earthquake swarms, relatively frequent minor earthquakes, and infrequent major earthquakes.

Three significant earthquakes affected the Santa Barbara Channel area in 1812, 1857, and 1925, prior to the time covered by the Southern California Earthquake Data Center (2010) catalog; however, locations in the northern Santa Barbara Channel have been reported (Sylvester and others, 1970) for both the 1925 event (M 6.3) and the largest earthquake (M 5.5, 7/1/1941), which is shown on Map C (sheet 9). In addition, Sylvester and others (1970) documented a swarm of 62 earthquakes (M $2.5-\mathrm{M}$ 5.2) that occurred between 6/26/1968 and 8/3/1968, which also were located 10 to $15 \mathrm{~km}$ south (offshore) of Santa Barbara. The largest event ( $\mathrm{M}$ 4.8) in the Hueneme Canyon and vicinity map area occurred on 3/18/1957 near Port of Hueneme.

\section{Thickness and Depth to Base of Uppermost Pleistocene and Holocene Deposits}

Maps on sheet 9 show the thickness and the depth to base of uppermost Pleistocene and Holocene (post-LGM) deposits both for the Hueneme Canyon and vicinity map area (Maps A, B) and, to establish regional context, for a larger area (about $115 \mathrm{~km}$ of coast) that extends from the vicinity of Hueneme Canyon northwest to the Refugio Beach area (Maps D, E). To make these maps, water bottom and depth to base of the LGM horizons were mapped from seismic-reflection profiles using Seisworks software. The difference between the two horizons was exported from Seisworks for every shot point as XY coordinates (UTM zone 11) and two-way travel time (TWT). The thickness of the post-LGM unit (Maps B, E) was determined by applying a sound velocity of $1,600 \mathrm{~m} / \mathrm{sec}$ to the TWT, resulting in thicknesses as great as $65 \mathrm{~m}$. The thickness points were interpolated to a preliminary continuous surface, overlaid with zero-thickness bedrock outcrops (see Ritchie and others, sheet 10 of this report), and contoured (Wong and others, 2012). Data within Hueneme Canyon were excluded from the contouring because the seismic-reflection data are too sparse to adequately image the highly variable changes in sediment thickness that characterize the canyon (Maps A, B, D, E). 
Several factors required manual editing of the preliminary thickness maps to make the final product. The Red Mountain Fault Zone, Pitas Point Fault, and Oak Ridge Fault disrupt the sediment sequence in the region (Maps D, E, on sheet 9). The data points also are dense along tracklines (about 1 $\mathrm{m}$ apart) and sparse between tracklines (1-2 km apart), resulting in contouring artifacts. To incorporate the effect of the faults, to remove irregularities from interpolation, and to reflect other geologic information and complexity, the resulting interpolated contours were modified. Contour modifications and regridding were repeated several times to produce the final regional sediment-thickness map (Wong and others, 2012).

The depth-to-base data available from Seisworks were similarly processed and contoured; however, this preliminary data set was set aside in favor of a surface determined by subtracting the modified thickness data from multibeam bathymetry collected separately (see sheet 1) and using 1,500 $\mathrm{m} / \mathrm{sec}$ for TWT in the water column. The depth of this surface in the Hueneme Canyon to Refugio Beach area ranges from 12 to $190 \mathrm{~m}$ (Map D on sheet 9; see also, Wong and others, 2012).

Five different "domains" of sediment thickness, which are bounded either by faults or by Hueneme Canyon, are recognized on the regional maps (Maps D, E, on sheet 9): (1) north of the northern strand of the Red Mountain Fault Zone; (2) between the northern strand of the Red Mountain Fault Zone and the Pitas Point Fault; (3) between the Pitas Point and Oak Ridge Faults; (4) between the Oak Ridge Fault and Hueneme Canyon; and (5) south of Hueneme Canyon. Table 7-1 shows the area of these five domains, along with estimates of their mean sediment thickness and total sediment volume. These data highlight the contrast among three general zones of sediment thickness: (1) the uplifted, sediment-poor Santa Barbara shelf (domain 1; mean sediment thickness of $3.6 \mathrm{~m}$ ); (2) a transitional zone

Table 7-1. Area, sediment-thickness, and sediment-volume data for California's State Waters in Santa Barbara Channel region, between Refugio Beach and Hueneme Canyon areas (domains 1-5), as well as in Hueneme Canyon and vicinity map area and in two areas within map area.

[Data from within Hueneme Canyon were not included in this analysis]

\begin{tabular}{|c|c|c|c|}
\hline \multicolumn{4}{|c|}{ Regional sediment-thickness domains in Santa Barbara Channel region } \\
\hline & Area $\left(\mathrm{km}^{2}\right)$ & $\begin{array}{l}\text { Mean sediment } \\
\text { thickness }(\mathrm{m})\end{array}$ & $\begin{array}{l}\text { Sediment volume } \\
\qquad\left(10^{6} \mathrm{~m}^{3}\right)\end{array}$ \\
\hline $\begin{array}{l}\text { (1) Refugio Beach to northern strand of Red Mountain } \\
\text { Fault Zone }\end{array}$ & 356.57 & 3.6 & $1,268.13$ \\
\hline $\begin{array}{l}\text { (2) Northern strand of Red Mountain Fault Zone to Pitas } \\
\text { Point Fault }\end{array}$ & 68.18 & 17.6 & $1,200.23$ \\
\hline (3) Pitas Point Fault to Oak Ridge Fault & 69.64 & 39.3 & $2,740.13$ \\
\hline (4) Oak Ridge Fault to Hueneme Canyon & 74.80 & 38.7 & $2,897.05$ \\
\hline (5) South of Hueneme Canyon & 53.91 & 28.3 & $1,527.15$ \\
\hline \multicolumn{4}{|c|}{ Sediment thicknesses in Hueneme Canyon and vicinity map area } \\
\hline Entire Hueneme Canyon and vicinity map area & 110.33 & 35.5 & $3,920.68$ \\
\hline Map area northwest of Hueneme Canyon & 64.96 & 38.1 & $2,472.64$ \\
\hline Map area southeast of Hueneme Canyon & 45.37 & 31.9 & $1,448.04$ \\
\hline
\end{tabular}


(domain 2; mean sediment thickness of $17.6 \mathrm{~m}$ ); and (3) the subsiding, sediment-rich delta and shelf offshore of the Ventura and Santa Clara Rivers and Calleguas Creek (domains 3, 4, and 5; mean sediment thicknesses of $39.3,38.7$, and $28.3 \mathrm{~m}$, respectively).

In the Hueneme Canyon and vicinity map area, thickness data reveal that the post-LGM deposits northwest of Hueneme Canyon typically are about 35 to $45 \mathrm{~m}$ thick (mean thickness, $38.1 \mathrm{~m}$; table 7-1). The highest variation in thickness is found on the northwest flank of the canyon where thickness varies from about 25 to $45 \mathrm{~m}$, owing to cut and fill of channels and also to vertical offsets on north-northeaststriking faults (see sheets 8 and 10). The depth to base of the post-LGM is 50 to $60 \mathrm{~m}$ for most of the area northwest of Hueneme Canyon and, as with sediment thickness, has the most variation adjacent to the canyon.

Uppermost Pleistocene and Holocene (post-LGM) deposits are less thick on the shelf southeast of Hueneme Canyon, ranging in thickness from about 20 to $45 \mathrm{~m}$ (mean thickness, $31.9 \mathrm{~m}$; table 7-1). The variability reflects the influence of channel cut and fill associated with the heads of the smaller, unnamed submarine canyons east of Hueneme Canyon, as well as perhaps the lower sediment supply owing to their location on the downdrift flank of Hueneme Canyon. The depth to base of the post-LGM unit beneath the shelf ranges from 40 to about $80 \mathrm{~m}$, notably deeper than northwest of Hueneme Canyon. The difference in sediment thickness between the northwest and southwest sides of the canyon indicates that the coastline at the time of the LGM had a more northwesterly trend and that it has rotated clockwise during the post-LGM transgression. 


\title{
Chapter 8. Geologic and Geomorphic Map of Hueneme Canyon and Vicinity (Sheet 10) and Detailed Geology/Geomorphology, Slope, and Curvature Maps of Hueneme Canyon (Sheet 11)
}

\author{
By Andrew C. Ritchie and Samuel Y. Johnson
}

\section{Geologic and Geomorphic Summary}

Marine geology and geomorphology was mapped in the Hueneme Canyon and vicinity map area from approximate Mean High Water (MHW) to the 3-nautical-mile limit of California's State Waters, and even farther offshore on the east and west flanks of Hueneme Canyon. MHW is defined at an elevation of $1.33 \mathrm{~m}$ above the North American Vertical Datum of 1988 (NAVD 88) (Weber and others, 2005).

The offshore part of Hueneme Canyon and vicinity map area is characterized by two major physiographic features: (1) the nearshore, the inner and outer continental shelf, and the upper slope, and (2) Hueneme Canyon and parts of three smaller, unnamed submarine canyons incised into the shelf southeast of Hueneme Canyon. The nearshore, shelf, and slope, which are underlain by recent sediments, are characterized by active sediment transport. Nearshore and inner shelf deposits are predominantly sand (unit Qms), as determined by camera observations (see sheet 6) and sampling (see, for example, Reid and others, 2006). These sandy shelf deposits locally include areas of rippled scour depressions (unit Qmss; see, for example, Cacchione and others, 1984; Murray and Theiler, 2004) and hummocky relief (unit Qmsh). Outer shelf and slope deposits consist of mixed sand and mud (unit $\mathrm{Qmsl}$ ) that locally contains solitary or groups of pockmarks (unit Qmp) or is incised by narrow rills (unit Qmr).

The morphology and evolution of shelf and slope result from sedimentation as sea level rose about 125 to $130 \mathrm{~m}$ over the last about 21,000 years (Fairbanks, 1989; Lambeck and Chappell, 2001). Sea-level rise (controlled by both eustasy and tectonic land-level change) was apparently not steady during this period, leading to development of shoreline angles and adjacent submerged wave-cut platforms and risers (Kern, 1977). These features commonly are buried by shelf sediment. However, their original morphology is at least partly preserved along the outer shelf and upper slope on the east flank of Hueneme Canyon, as best illustrated on the 1:12,000- and 1:18,000-scale maps on sheet 11 . Geologic map units (Map A on sheet 11) include four wave-cut platforms (units Qwp1, Qwp2, Qwp3, Qwp4) and risers (units Qwpr1, Qwpr2, Qwpr3, Qwpr4), separated by shoreline angles at depths of approximately $65 \mathrm{~m}, 75$ to $85 \mathrm{~m}, 95$ to $100 \mathrm{~m}$, and 120 to $125 \mathrm{~m}$. The deepest paleoshoreline (about 120 $m$ deep) approximately corresponds to sea level during the final stages of the last sea-level lowstand, and the most shallow (about $65 \mathrm{~m}$ deep) paleoshoreline correlates with a pulse of relative sea-level stability during the Younger Dryas cold climate period between about 12,800 and 11,500 years ago (Fairbanks, 1989; Alley, 2000; Lambeck and Chappell, 2001).

Hueneme Canyon extends about $15 \mathrm{~km}$ offshore from its nearshore canyon head. The canyon initially formed by incision by an ancestral Santa Clara River during sea-level lowstand(s) and subsequently was further deepened by erosive submarine turbidity currents. The canyon is relatively deep (about $150 \mathrm{~m}$ at the California's State Waters 3-nautical-mile limit) and steep (canyon walls as steep as $25^{\circ}$ to $30^{\circ}$ ). The heads of the three smaller unnamed canyons southeast of Hueneme Canyon are not connected to the nearshore zone; however, during the last sea-level lowstand, these smaller canyons were connected to coastal watersheds that fed coarse-grained sediment directly to the Hueneme submarine fan (Normark and others, 2009). In the ensuing transgression, Hueneme Canyon maintained its connection with the shoreline as it eroded headward, whereas these smaller canyons became isolated 
and abandoned. Romans and others (2009) suggested that the latest phase of Hueneme Canyon incision occurred between 7,000 and 2,000 years ago when the Santa Clara River flowed directly into the canyon head, an inference based on the onshore mapping of Santa Clara River alluvial channels and terraces on the adjacent onshore Oxnard plain (Clahan, 2003); they further suggested that the course of the Santa Clara River migrated $8 \mathrm{~km}$ to the north in the latest Holocene.

Outer canyon walls, which extend upward to the shelf edge, in both Hueneme Canyon and the smaller canyons vary from smooth (sediment draped) (unit Qcwo1) to deeply incised (unit Qcwo2). Inner canyon walls (unit Qcwi) occupy an intermediate position between the shelf edge and canyon floor.

Both outer and inner canyon walls were formed primarily by landsliding. Three different landslide-deposit units (units Qls1, QIs2, and QIs3, listed oldest to youngest) are mapped in Hueneme Canyon on the basis of their morphology and relative age (inferred from crosscutting and (or) draping relations). A fourth undifferentiated landslide-deposit unit (QIs) is mapped where these morphology and relative-age indicators are not distinct. The landslide map units commonly include steep erosional scarps paired with hummocky landslide deposits; this genetic pairing (scarps and landslide deposits) distinguishes the internal scarps within landslide units from the head scarps within canyon-wall units. Lower relief, sediment-draped, deep-seated slumps are mapped as a fifth landslide-deposit unit (QIss).

Submarine-canyon channel heads (unit Qcch) are delineated on the basis of their incision into the nearshore (Hueneme Canyon), outer shelf (three smaller canyons southeast of Hueneme Canyon), or slope (eastern margin of Hueneme Canyon), as well as their relatively steep gradients and their Vshaped profiles. These channel heads transition into lower gradient and more flat-bottomed canyon-floor channel deposits (unit Qccf). The Hueneme Canyon channel floor is a zone of active sediment transport characterized by large, asymmetric bedforms bounded by steep channel walls (unit Qccw). Narrow, elongate channel-flanking bars (unit Qccb) are elevated above, and are morphologically distinct from, the channel floors and, thus, are broken out as separate units.

In addition to the landslide and canyon-channel deposits, three types of sedimentary canyon fill are recognized. Axial-submarine-canyon-fill deposits (unit Qcfa), which form elevated surfaces 20 to 50 $\mathrm{m}$ above the floors of Hueneme Canyon and the smaller submarine canyons and which dip gently downcanyon, are composed of well-stratified sediment (sand, mud, gravel?), recognized on the basis of seismic-reflection facies (high frequency, moderate amplitude, and parallel reflections). Lateralsubmarine-canyon fill deposits (unit Qcfl), located on the east flank of Hueneme Canyon near its head, consist of west-dipping, stratified sediment (similar seismic facies) that may have formed as distributed fluvial input into the canyon in the middle to late Holocene. Tributary-submarine-canyon-fill deposits (unit Qcft) are inferred to have formed as direct fluvial entrants into the canyons in the middle to late Holocene and, subsequently, were partly filled by nearshore and shelf sediment during sea-level rise.

One exposure of undifferentiated bedrock (unit Tbu) is recognized in the map area, on the slope on the west flank of Hueneme Canyon channel, at a depth of about 300 to $350 \mathrm{~m}$. This unit is recognized on the basis of its high backscatter (see sheet 3 ) and its massive character on seismic-reflection data (Sliter and others, 2008; profiles HC-14 and HC-15). Greene and others (1978; their plate 2) previously mapped this bedrock as the Miocene Monterey Formation.

Cumulatively, shelf and slope deposits and submarine-canyon deposits make up about 86 percent and 14 percent of the map area, respectively. The four main categories of geologic map units within the Hueneme Canyon and vicinity map area are, in the following proportions: canyon-wall deposits, 47 percent; landslide deposits, 30 percent; canyon-channel deposits, 10 percent; and canyon-fill deposits, 13 percent. The relatively small proportion of canyon-channel and canyon-fill map units emphasizes the role of the nearshore canyon as a zone of sediment bypass and transport, not deposition.

In addition to the detailed geology/geomorphology map of Hueneme Canyon, sheet 11 includes a slope map and a curvature map (Maps B and C, respectively), both of which highlight other important 
attributes of Hueneme Canyon that were used to help distinguish different geologic and geomorphic map units. The slope map emphasizes the flat shelf that bounds the canyon, the steep (commonly steeper than $18^{\circ}$ ) canyon walls, the moderately steeply sloping landslide deposits, and the lower slope canyonchannel and -fill deposits. Figure 1 on sheet 11 illustrates the "step-pool" nature of the main canyon channel, suggesting that channel bedforms may be migrating upchannel at the same time as sediment is being transported downchannel. The curvature map most notably highlights substantial canyon-normal, dendritic incision into canyon walls and landslide deposits. These incised drainages must postdate initial development of the canyon walls and the landslides, and they serve as conduits for transporting sediment from the shelf to the canyon floor. The curvature map also clearly documents the wave-cut platformriser morphology of the submerged shorelines that are present near the shelf break on the east flank of Hueneme Canyon (fig. 2 on sheet 11). 


\title{
DESCRIPTION OF MAP UNITS
}

\section{OFFSHORE GEOLOGIC AND GEOMORPHIC UNITS}

\author{
af Artificial fill (Holocene)—Rock, sand, and mud; placed and (or) dredged. Also \\ includes seafloor significantly modified by human activity \\ Qms Marine nearshore and shelf deposits (Holocene)_Predominantly sand; ripple \\ marks common. Found on seaward-dipping surface that extends from \\ shoreline to either shelf break (about $80 \mathrm{~m}$ deep) or to sharp rims of submarine \\ canyons. Surface typically dips $1^{\circ}$ to $4^{\circ}$ from shoreline to about $10 \mathrm{~m}$ deep; \\ less than $1^{\circ}$ from about 10 to $40 \mathrm{~m}$ deep; and $1^{\circ}$ to $3^{\circ}$ from about $40 \mathrm{~m}$ deep to \\ shelf break
}

Qmss Marine shelf scour depressions (Holocene) - Inferred to be coarse sand and possibly gravel, found as single depressions or in fields of depressions interspersed with elevated shelf sediments (unit Qms); consists of irregular arcuate scour depressions that vary from solitary features occupying a few hundred square meters to fields of interconnected depressions covering tens of thousands of square meters. Depressions typically are 15 to $50 \mathrm{~cm}$ deep, and they have diffuse boundaries on their shoreward edge that grade to sharp, well-defined boundaries on their offshore edge. Although no direct camera observations of these depressions were made in this area, their composition is inferred from similar features directly observed elsewhere on California shelf. General location of unit is not likely to change substantially, but its boundaries are likely ephemeral, changing during significant storm events, as are locations of individual depressions and intervening flat sheets

Qmsh Marine shelf hummocky deposits (Holocene) - Sand forming hummocky surface relief on shelf. Hummocks typically are 100 to $150 \mathrm{~cm}$ high, several hundred meters in diameter, and 40 to $45 \mathrm{~m}$ deep, and they lie immediately downslope of, and are aligned with, unit Qmr along east edge of map area

Qmsl Marine slope deposits (Holocene) - Sand and mud, found offshore of shelf break (more than about $80 \mathrm{~m}$ deep) on seaward-dipping $\left(6^{\circ}-8^{\circ}\right)$ surface

Qmp Marine pockmarks (Holocene) — Sand and mud, forming pockmarks on outer shelf and slope. Pockmarks are solitary or grouped, circular to elliptical, and range in size from 50 to $100 \mathrm{~m}$ along their long axis, and they typically are 50 to 400 $\mathrm{cm}$ deep and ringed with convex rim about $50 \mathrm{~cm}$ high. On shelf, pockmarks mostly are circular and have elevated rim, whereas on slope they generally are elongate or elliptical, with major axis oriented perpendicular to slope and convex rim on downslope side only. Pockmark regions occupy about 0.5 percent of shelf and slope

Qmr Marine rill (Holocene) - Probably sand and mud, forming narrow (40 to $90 \mathrm{~m}$ wide), elongate ( 0.5 to $3.7 \mathrm{~km}$ long), and shallow (30 to $400 \mathrm{~cm}$ deep) channels, or rills, cut into middle to outer shelf and slope

Qwp4 Submerged wave-cut platform, about $65 \mathrm{~m}$ deep (latest Pleistocene) - Inferred to be sand and gravel. Best developed in smaller unnamed canyons east of Hueneme Canyon. Platform is as wide as $250 \mathrm{~m}$, dips as much as $4^{\circ}$ offshore, and can be traced laterally for $1 \mathrm{~km}$ in easternmost canyon; bounded upslope 
by paleoshoreline angle (Kern, 1977) and unit Qwpr4. Platform is shallowest and youngest of four platforms inferred to have been formed by wavecutting in periods of relative sea-level stillstands during overall sea-level rise following Last Glacial Maximum (Fleming and others, 1998)

Qwpr4 Submerged wave-cut platform riser, base about 65 m deep (latest Pleistocene)Inferred to be sand and gravel. Smooth, offshore-dipping (as much as $23^{\circ}$ ) surface as wide as $100 \mathrm{~m}$; upper contact is continental shelf, whereas lower contact is paleoshoreline angle (Kern, 1977). Riser represents paleo-sea cliff or onshore slope associated with development of wave-cut platform of unit Qwp4

Qwp3 Submerged wave-cut platform, about 75 to 85 m deep (latest Pleistocene)Inferred to be sand and gravel. Best developed on outer shelf on east flank of Hueneme Canyon; also visible in smaller unnamed canyons east of Hueneme Canyon. Platform, which is as wide as $500 \mathrm{~m}$ and generally dips less than $2^{\circ}$ offshore, can be traced for $3 \mathrm{~km}$ on east flank of Hueneme Canyon; bounded upslope by paleoshoreline angle (Kern, 1977) and unit Qwpr3. Platform is next to youngest and most extensive of four platforms inferred to have been formed by wavecutting in periods of relative sea-level stillstands during overall sea-level rise following Last Glacial Maximum (Fleming and others, 1998)

Qwpr3 Submerged wave-cut platform riser, base about 75 to $85 \mathrm{~m}$ deep (latest Pleistocene) - Inferred to be sand and gravel. Smooth, offshore-dipping (as much as $24^{\circ}$ ) surface as wide as $120 \mathrm{~m}$; lower contact is paleoshoreline angle (Kern, 1977). Riser represents paleo-sea cliff or onshore slope associated with development of wave-cut platform of unit Qwp3

Qwp2 Submerged wave-cut platform, about 95 to $100 \mathrm{~m}$ deep (latest Pleistocene) Inferred to be sand and gravel. Best developed on outer shelf on east flank of Hueneme Canyon. Platform, which is as wide as $200 \mathrm{~m}$ and dips $0.5^{\circ}$ to $3.5^{\circ}$ offshore, can be traced for $1.5 \mathrm{~km}$; bounded upslope by paleoshoreline angle (Kern, 1977) and unit Qwpr2. Platform is second deepest of four platforms inferred to have been formed by wavecutting in periods of relative sea-level stillstands during overall sea-level rise following Last Glacial Maximum (Fleming and others, 1998)

Qwpr2 Submerged wave-cut platform riser, base about 95 to $100 \mathrm{~m}$ deep (latest Pleistocene) - Inferred to be sand and gravel. Smooth, offshore-dipping (as much as $20^{\circ}$ ) surface as wide as $150 \mathrm{~m}$; lower contact is paleoshoreline angle (Kern, 1977). Riser represents paleo-sea cliff or onshore slope associated with development of wave-cut platform of unit Qwp2

Qwp1 Submerged wave-cut platform, about 120 to 125 m deep (latest Pleistocene)Inferred to be sand and gravel. Best developed on outer shelf on east flank of Hueneme Canyon. Platform, which is as wide as $200 \mathrm{~m}$ and dips $2^{\circ}$ to $4^{\circ}$ offshore, can be traced for $1.2 \mathrm{~km}$; bounded upslope by paleoshoreline angle (Kern, 1977) and unit Qwpr1. Platform is deepest and oldest of four platforms inferred to have been formed by wavecutting in periods of relative sea-level stillstands after Last Glacial Maximum (Fleming and others, 1998)

Qwpr1 Submerged wave-cut platform riser, base about 120 to $125 \mathrm{~m}$ deep (latest Pleistocene) - Inferred to be sand and gravel. Smooth, offshore-dipping ( $8^{\circ}-$ 
$10^{\circ}$ ) surface as wide as $125 \mathrm{~m}$; lower contact is paleoshoreline angle (Kern, 1977). Riser represents paleo-sea cliff or onshore slope associated with development of wave-cut platform of unit Qwp1

Tbu Bedrock, undivided (Pliocene? and Miocene)-Mapped on basis of its rugosity, high backscatter (see sheet 3), and massive character on seismic-reflection profiles. Greene and others (1978, their plate 2) mapped these rocks as the Miocene Monterey Formation, which primarily consists of mudstone and shale

\section{SUBMARINE CANYON}

Qcch Submarine-canyon channel-head deposits (Holocene)-Probably sand and gravel(?), incised into shelf (unit Qms) or slope (unit Qmsl) deposits. In contact with artificial fill (unit af) at head of Hueneme Canyon. Characterized by relatively steep gradients and $\mathrm{V}$-shaped profiles relative to lower gradient canyon-floor channel deposits (units Qccf, Qccw, Qccb)

Qccf Submarine-canyon channel-floor deposits (Holocene)-Inferred to be sand and gravel. Forms curvilinear, submarine-canyon channel floor in Hueneme Canyon, as well as canyon-floor channel in unnamed canyon east of Hueneme Canyon and small part of canyon floor in unnamed canyon in southeast corner of map area. In Hueneme Canyon, width of channel floor ranges from 25 to $100 \mathrm{~m}$. Slope of Hueneme Canyon channel floor, which decreases from $5.6^{\circ}$ at canyon head to $1.3^{\circ}$ over distance of about $9 \mathrm{~km}$, is characterized by rhythmic, stepped-plunge morphology having downstream-facing, crescent-shaped bedforms spaced 50 to $150 \mathrm{~m}$ apart. These bedforms are asymmetrical, having upstream faces less than $4^{\circ}$ and downstream faces as steep as $10^{\circ}$; channelfloor depressions between bedforms are several meters deep

Qccb Submarine-canyon channel-flanking bar deposits (Holocene) - Inferred to be sand, mud, and gravel. Depositional origin; forms elongate features deposited by recent downcanyon sediment transport

Qccw Submarine-canyon channel-wall deposits (Holocene) - Inferred to be sand, mud, and gravel. Steep (mostly more than $18^{\circ}$, commonly more than $30^{\circ}$ ) walls on margins of active channel floor in Hueneme Canyon. Erosional origin; formed by incision of canyon fill. Crosscut in places by landslide deposits (unit QIs3) and by dredged channel at Port of Hueneme; locally absent along channel margin, where axial-channel fill (unit Qcfa) grades to channel-floor deposits (unit Qcc) or channel-flanking bar deposits (unit Qccb)

Qcwi Inner submarine-canyon-wall deposits (latest Pleistocene and Holocene) Inferred to be sand, mud, and gravel. Primarily intracanyon walls dipping mostly more than $12^{\circ}$ and commonly more than $20^{\circ}$; also includes one intracanyon ridge that has ridgetop slope of more than $6^{\circ}$. Relatively smooth surface within Hueneme Canyon. Erosional origin; formed by Holocene incision and Holocene to present-day landsliding. Lower boundary lies above active canyon floor (distinguishable from unit Qccw); upper boundary lies below continental shelf (distinguishable from units Qcwo1 and Qcwo2)

Qcwo2 Outer submarine-canyon-wall deposits (latest Pleistocene and Holocene) Inferred to be sand and gravel. Typically steep (commonly more than $18^{\circ}$, mostly more than $30^{\circ}$ ); upper surface is commonly slope-break contact with 
continental shelf or slope. Primary erosional origin; deeply incised by Vshaped gullies that have well-defined, sharp-edged ridges; also includes some landslide scarps that cannot be directly tied to landslide deposits (and, thus, are not mapped as such). Gradational with unit Qcwo1 at shelf break

Qcwo1 Outer submarine-canyon-wall deposits (latest Pleistocene and Holocene) -

Inferred to be sand, mud and gravel. Typically steep (commonly more than $18^{\circ}$, rarely more than $30^{\circ}$ ) but has more gentle slope-break contact with continental shelf or slope. Primarily of erosional origin but commonly draped by variable amounts of shelf-derived sand. Gradational with unit Qcwo2 in a few inner gorges but generally distinguishable from it by lower average slope and smoother gullies

Qls3 Landslide deposits, third generation (Holocene) - Scarps, chutes, and lobes, inferred to be sand and gravel. Scarps typically form steep (more than $18^{\circ}$ ) concave surfaces; lobes form hummocky mounds. Mapped as youngest landslide deposits in Hueneme Canyon on basis of crosscutting or overlapping relations with other landslide or canyon-fill deposits

QIs2 Landslide deposits, second generation (Holocene and latest Pleistocene) — Scarps, chutes, and lobes, inferred to be sand and gravel. Scarps typically form steep (more than $15^{\circ}$ ) concave surfaces; lobes form hummocky mounds. Mapped as intermediate-age landslide deposits in Hueneme Canyon on basis of crosscutting or overlapping relations with inferred younger and older landslide or canyon-fill deposits

Qls1 Landslide deposits, first generation (Holocene and latest Pleistocene) - Scarps, chutes, and lobes, inferred to be sand and gravel. Scarps typically form moderately sloping (less than $15^{\circ}$ ), smooth (inferred to be sediment draped) concave surfaces, grading to deposits that have concave-to-convex curvature; lobes form low-relief, hummocky mounds. Mapped as oldest landslide deposits in Hueneme Canyon on basis of muted expression, as well as crosscutting or overlapping relations with inferred younger landslide or canyon-fill deposits

QIs Landslide deposits, undifferentiated (latest Pleistocene and Holocene) - Scarps, chutes, and lobes, inferred to be sand and gravel. Located within smaller unnamed submarine canyons east of Hueneme Canyon. Scarps typically form steep (more than $18^{\circ}$ ) concave surfaces; lobes form hummocky mounds whose surfaces generally slope less than $9^{\circ}$

Qlss Slump deposits on canyon walls (Holocene and latest Pleistocene)-Probably sand. Large $\left(0.56 \mathrm{~km}^{2}\right)$ channel-blocking slump in unnamed canyon east of Hueneme Canyon. Also includes large (about $1.0 \mathrm{~km}^{2}$ ) semicircular slump in continental slope deposits (unit Qmsl) on west flank of Hueneme Canyon and smaller (about $28,000 \mathrm{~m}^{2}$ ) rotational slump that has sharply defined headscarp near head of Hueneme Canyon

Qcft Tributary-submarine-canyon fill (Holocene) — Inferred to be sand and gravel(?). Includes three tributary submarine channels, two at mouth of Hueneme Canyon and one to smaller unnamed canyon at east edge of map area. Two Hueneme Canyon channels, which are about $350 \mathrm{~m}$ wide, probably formed as alluvial entrants into canyon head that were subsequently filled with fluvial and nearshore sediments during sea-level rise 
Qcfl Lateral-submarine-canyon fill (Holocene) - Inferred to be mud, sand, and gravel. West-dipping (about $7^{\circ}$ ) surface on east flank of Hueneme Canyon, near canyon head. Consists of west-dipping, stratified sediment mapped on basis of seismic-reflection data (specifically, high-frequency, moderate-amplitude, parallel reflections)

Qcfa Axial-submarine-canyon fill (Holocene) - Inferred to be sand and gravel. Elevated, relatively flat (dips $2^{\circ}$ to almost $9^{\circ}$ ), smooth surface incised by canyon-floor channel. Dip generally is downcanyon. Forms terrace-like surfaces that are found along, and as much as $50 \mathrm{~m}$ above, active floor of Hueneme Canyon. Composed of well-stratified sediments mapped on basis of seismic-reflection data (specifically, high-frequency, moderate-amplitude, parallel reflections)

\title{
ONSHORE GEOLOGIC AND GEOMORPHIC UNITS
}

[Compiled from Clahan (2003)]

\begin{abstract}
af Artificial fill (Holocene) - Engineered and (or) nonengineered
alf Artificial-levee fill (Holocene) - Engineered and (or) nonengineered

$\mathrm{Qb}$

Beach deposits (Holocene) - Unconsolidated, loose, fine- to coarse-grained sand, well sorted. Mapped in coastal band from shoreline to highest elevation of swash zone
\end{abstract}

Qe

Coastal eolian sand-dune deposits (Holocene) - Well-sorted, loose sand and silt. Varies from nonvegetated surfaces that include ephemeral wind ripples to typical dune-vegetated areas that have thin soil veneers. Mapped in narrow (as wide as $1 \mathrm{~km}$ ) coastal strip adjacent to, and above, beach; includes low dunes as tall as 12 meters

Qes Coastal-estuarine deposits (Holocene) - Silty clay. In mud flats that flood during high tides; also in marshland areas that lie slightly above mean sea level and have brackish conditions. Deposits have very limited areal extent, mapped only in erosion-protected areas landward of unit $\mathrm{Qe}$

Qa Alluvial deposits (Holocene) - Unconsolidated, poorly sorted, clayey sand and some gravel; deposited as overbank material associated with unit Qw3; recognized by scour and incised channels

Qa3 Alluvial deposits (Holocene) - Unconsolidated, poorly sorted, clayey sand and some gravel; deposited as overbank material associated with unit Qw3; recognized by scour and incised channels

Qw3 Wash deposits (Holocene) — Unconsolidated sand, silt, and gravel. Located in major abandoned river channels

Qt

Qa2

Stream-terrace deposits (Holocene) - Unconsolidated clayey sand, sandy clay, and gravel; deposited in point-bar and overbank settings associated with unit Qw3

Alluvial deposits (Holocene) - Unconsolidated, poorly sorted, clayey sand and some gravel; deposited as overbank material associated with unit Qw2; recognized by scour and incised channels

Qw2 Wash deposits (Holocene) - Unconsolidated sand, silt, and gravel. Located in major abandoned river channels

Qa1 Alluvial deposits (Holocene) - Unconsolidated, sandy clay and some gravel; deposited as overbank material associated with unit Qw1; recognized by scour and incised channels 
Qw1 Wash deposits (Holocene)_Unconsolidated sand, silt, and gravel. Located in major abandoned river channels

Qff Alluvial fan deposits (Holocene) — Fine-grained alluvial fan and floodplain overbank deposits. Fine facies; predominantly clay and interbedded lenses of coarser sand and gravel. Located on very gently sloping parts of valley floor 


\title{
Chapter 9. Predictive Distribution of Benthic Macro-Invertebrates for Hueneme Canyon and Vicinity Map Area and the Santa Barbara Channel Region (Sheet 12)
}

\author{
By Lisa M. Krigsman, Mary M. Yoklavich, Nadine E. Golden, and Guy R. Cochrane
}

Modeling the distribution of ecologically and economically important species provides managers and conservation planners with information on a broad spatial scale that is useful to coastal management, ocean energy, marine protected areas, and marine spatial planning (Krigsman and others, 2012). Sheet 12 displays predictive models of occurrence for common benthic macro-invertebrate taxa and maps the probability of occurrence of these taxa in the Santa Barbara Channel. These models are based on real-time biological observations of all macro-organisms made during ground-truth surveys (sheet 6) conducted in 2008 and 2009; the observations were made during a 10-second interval every minute along camera transects, which were approximately $1 \mathrm{~km}$ in length (sheet 6 ; see also, chapter 5 of this pamphlet).

Five invertebrate taxa - cup corals, hydroids, short sea pens, tall sea pens, and brittle stars (which protrude out of the sediment) - were selected for modeling purposes on the basis of their frequent occurrence in the Santa Barbara Channel. Presence-absence data for the selected invertebrates were fit to multiple generalized linear models using a combination of three covariates - geographic location, seafloor character (sheet 5), and shaded-relief bathymetry (sheet 2) - as well as relevant interaction terms. Best-fit models were selected for each invertebrate based on Akaike's Information Criterion (AIC) (Akaike, 1974), a best-fit model being defined as the one with fewest parameters within two AIC points of the minimum score.

The seafloor in the Hueneme Canyon and vicinity map area is predominantly Class 1 (unconsolidated sediment); areas assigned to Class 2 (mixed habitat) in the map area extend beyond the boundaries of California's State Waters; and no observations of Class 3 (rugose rock) have been made in the map area (sheet 5). Predictions for this map area are constrained to depths of between 5 and $150 \mathrm{~m}$ owing to the limitations of the camera sled. This means that model predictions for the Hueneme Canyon and vicinity map area are limited to the edges of the canyon, the continental shelf, and the upper continental slope.

Because the Hueneme Canyon and vicinity map area is predominantly Class 1 , an overall low probability of observing cup corals exists in this area (Map D on sheet 12). Cup corals are a benthic Cnidarian typically found on rocky sediment. A moderate (about 60\%) probability of occurrence is predicted for cup corals on mixed sediment and rugose rock in deep water, but, again, deep water is outside of the boundaries of California's State Waters. A moderate probability of occurrence exists for hydroids (Map C on sheet 12), another benthic Cnidarian, around the edge of Hueneme Canyon and in the nearshore south of Port of Hueneme. South of Hueneme Canyon, the probability of occurrence for hydroids increases with depth.

Sea pens, also members of the Cnidarian family, are divided into two groups — short and tall—on the basis of their size. Sea pens less than $60 \mathrm{~cm}$ in height are identified as short sea pens; those greater than $60 \mathrm{~cm}$ are identified as tall sea pens (Maps A and B, respectively, on sheet 12). Although both types of sea pens are predicted to occur in soft sediment along the edge of Hueneme Canyon, the probability of occurrence is higher for short sea pens, whereas tall sea pens have a higher predicted probability of occurrence deeper into the canyon.

Brittle stars in the sediment can occur in such high densities that they create a thick carpet of arms on the seafloor. Brittle stars are another taxa predicted to have a high probability of occurrence in soft sediment along the edge of Hueneme Canyon and in deep water southeast of the canyon (Map E on sheet 12). 
Our predictive maps are based on data available from the California Seafloor Mapping Program (location, habitat type, and bathymetry). Other factors such as ocean currents (Cudaback and others, 2005), water temperature (Bingham and others, 1997), larval distribution (Grantham and others, 2003), and recruitment and mortality (Keough and Downes, 1982) can also significantly influence the distribution and abundance of these benthic macro-invertebrate taxa. 


\section{References Cited}

Aikake, H., 1974, A new look at the statistical model identification: Institute of Electrical and Electronics Engineers Transactions on Automatic Control, v. 19, p. 716-723.

Alley, R.B., 2000, The Younger Dryas cold interval as viewed from central Greenland: Quaternary Science Reviews, v. 19, p. 213-226.

Anderson, T.J., Cochrane, G.R., Roberts, D.A., Chezar, H., and Hatcher, G., 2007, A rapid method to characterize seabed habitats and associated macro-organisms, in Todd, B.J., and Greene, H.G., eds., Mapping the seafloor for habitat characterization: Geological Association of Canada Special Paper 47, p. 71-79.

Anima, R.J., Eittreim, S.L., Edwards, B.D., and Stevenson, A.J., 2002, Nearshore morphology and late Quaternary geologic framework of the northern Monterey Bay Marine Sanctuary, California: Marine Geology, v. 181, p. 35-54.

Barnard, P.L., Revell, D.L., Hoover, D., Warrick, J., Brocatus, J., Draut, A.E., Dartnell, P., Elias, E., Mustain, N., Hart, P.E., and Ryan, H.F., 2009, Coastal processes study of Santa Barbara and Ventura Counties, California: U.S. Geological Survey Open File Report 2009-1029, 926 p., available at http://pubs.usgs.gov/of/2009/1029/.

Bingham, B.L., Bacigalupi, M., and Johnson, L.G., 1997, Temperature adaptations of embryos from intertidal and subtidal sand dollars (Dendraster excentricus, Eschscholtz): Northwest Science, v. 71 (2), p. 108-114.

Briggs, J.C., 1974, Marine zoogeography: New York, McGraw-Hill, 480 p.

Cacchione, D.A., Drake, D.E., Grant, W.D., and Tate, G.B., 1984, Rippled scour depressions of the inner continental shelf off central California: Journal of Sedimentary Petrology, v. 54, p. 1,280-1,291.

Caldwell, R.J., Taylor, L.A., Eakins, B.W., Carignan, K.S., Grothe, P.R., Lim, E., and Friday, D.Z., 2010, Digital elevation models of Santa Monica, California - Procedures, data sources and analysis: NOAA Technical Memorandum NESDIS NGDC-46, NOAA National Geophysical Data Center, available at http://www.ngdc.noaa.gov/dem/squareCellGrid/download/663.

California Department of Fish and Game, 2008, California Marine Life Protection Act master plan for marine protected areas-Revised draft: California Department of Fish and Game, accessed April 5, 2011, at http://www.dfg.ca.gov/mlpa/masterplan.asp.

Carignan, K.S., Taylor, L.A., Eakins, B.W., Warnken, R.R., Lim, E., and Medley, P.R., 2009, Digital elevation model of Santa Barbara, California - Procedures, data sources, and analysis: NOAA Technical Memorandum NESDIS NGDC-29, NOAA National Geophysical Data Center, available at http://www.ngdc.noaa.gov/dem/squareCellGrid/download/603.

Chin, J.L., Clifton, H.E., and Mullins, H.T., 1988, Seismic stratigraphy and late Quaternary shelf history, south-central Monterey Bay, California: Marine Geology, v. 81, p. 137-157.

Clahan, K.B., 2003, Geologic map of the Oxnard 7.5' quadrangle, Ventura County, California-A digital database: California Geological Survey Preliminary Geologic Map, accessed April 5, 2011, at http://www.conservation.ca.gov/cgs/rghm/rgm/preliminary_geologic_maps.htm.

Cochrane, G.R., 2008, Video-supervised classification of sonar data for mapping seafloor habitat, in Reynolds, J.R., and Greene, H.G., eds., Marine habitat mapping technology for Alaska: Fairbanks, University of Alaska, Alaska Sea Grant College Program, p. 185-194, accessed April 5, 2011, at http://doc.nprb.org/web/research/research\%20pubs/615_habitat_mapping_workshop/Individual\%20C hapters\%20High-Res/Ch13\%20Cochrane.pdf.

Cochrane, G.R., Conrad, J.E., Reid, J.A., Fangman, S., and Golden, N., 2005, The nearshore benthic habitat GIS for the Channel Islands National Marine Sanctuary and southern California state fisheries 
reserves, Vol. II, Version 1.0: U.S. Geological Survey Open-File Report 2005-1170, accessed April 5, 2011, at http://pubs.usgs.gov/of/2005/1170/.

Cochrane, G.R., Nasby, N.M., Reid, J.A., Waltenberger, B., and Lee, K.M., 2003, Nearshore benthic habitat GIS for the Channel Islands National Marine Sanctuary and southern California state fisheries reserves, Vol. 1: U.S. Geological Survey Open-File Report 03-85, accessed April 5, 2011, at http:/geopubs.wr.usgs.gov/open-file/of03-85/.

Cudaback, C.N., Washburn, L., and Dever, E., 2005, Subtidal inner-shelf circulation near Point Conception, California: Journal of Geophysical Research, v. 110, C10007, doi:10.1029/2004JC002608.

Dahlen, M.Z., 1992, Sequence stratigraphy, depositional history, and middle to late Quaternary sea levels of the Ventura shelf, California: Quaternary Research, v. 38, p. 234-245.

Donnellan, A., Hager, B.H., and King, R.W., 1993, Discrepancy between geologic and geodetic deformation rates in the Ventura basin: Nature, v. 346, p. 333-336.

Draut, A.E., Hart, P.E., Lorenson, T.D., Ryan, H.F., Wong, F.L., Sliter, R.W., and Conrad, J.E., 2009, Late Pleistocene to Holocene sedimentation and hydrocarbon seeps on the continental shelf of a steep, tectonically active margin, southern California, USA: Marine Geophysical Research, p. 193-206, doi:10.1007/s11001-009-9076-y.

Fairbanks, R.G., 1989, A 17,000-year glacio-eustatic sea level record-Influence of glacial melting rates on the Younger Dryas event and deep-ocean circulation: Science, v. 342, p. 637-642.

Fisher, M.A., Greene, H.G., Normark, W.R., and Sliter, R.W., 2005, Neotectonics of the offshore Oak Ridge fault near Ventura, southern California: Bulletin of the Seismological Society of America, v. 95, p. 739-744.

Fisher, M.A., Sorlien, C.C., and Sliter, R.W., 2009, Potential earthquake faults offshore southern California from the eastern Santa Barbara channel to Dana Point, in Lee, H.J., and Normark, W.R., eds., Earth science in the urban ocean - The Southern California Continental Borderland: Geological Society of America Special Paper 454, p. 271-290.

Fleming, K., Johnston, P., Zwartz, D., Yokoyama, Y., Lambeck, K., and Chappell, J., 1998, Refining the eustatic sea-level curve since the Last Glacial Maximum using far- and intermediate-field sites: Earth and Planetary Science Letters, v. 163, p. 327-342, doi:10.1016/S0012-821X(98)00198-8.

Gornitz, V., 2009, Sea level change, post-glacial, in Gornitz, V., ed., Encyclopedia of paleoclimatology and ancient environments: New York, Springer, p. 887-893.

Gotshall, D.W., 2005, Guide to marine invertebrates-Alaska to Baja (2d ed.): Monterey, Calif., Sea Challengers, $117 \mathrm{p}$.

Grantham, B.A., Eckert, G.L., and Shanks, A.L., 2003, Dispersal potential of marine invertebrates in diverse habitats: Ecological Applications, v. 13(1), supplement p. S108-S116.

Greene, H.G., Bizzarro, J.J., O’Connell, V.M., and Brylinsky, C.K., 2007, Construction of digital potential marine benthic habitat maps using a coded classification scheme and its application, in Todd, B.J., and Greene, H.G., eds., Mapping the seafloor for habitat characterization: Geological Association of Canada Special Paper 47, p. 141-155.

Greene, H.G., Bizzarro, J.J., Tilden, J.E., Lopez, H.L., and Erdey, M.D., 2005, The benefits and pitfalls of geographic information systems in marine benthic habitat mapping, in Wright, D.J., and Scholz, A.J., eds., Place matters: Portland, Oregon State University Press, p. 34-46.

Greene, H.G., Wolf, S.C., and Blom, K.G., 1978, The marine geology of the eastern Santa Barbara Channel with particular emphasis on the ground water basins offshore from the Oxnard Plain, southern California: U.S. Geological Survey Open-File Report 78-305, 104 p., 13 plates. 
Greene, H.G., Yoklavich, M.M., Starr, R.M., O’Connell, V.M., Wakefield, W.W., Sullivan, D.E., McRea, J.E., and Cailliet, G.M., 1999, A classification scheme for deep seafloor habitats: Oceanologica Acta, v. 22, p. 663-678.

Griggs, G., Patsch, K., and Savoy, L., 2005, Living with the changing California coast: Berkeley, University of California Press, 540 p.

Grossman, E.E., Eittreim, S.L., Field, M.E., and Wong, F.L., 2006, Shallow stratigraphy and sedimentation history during high-frequency sea-level changes on the central California shelf: Continental Shelf Research, v. 26, p. 1,217-1,239.

Hapke, C.J., Reid, D., Richmond, B.B., Ruggiero, P., and List, J., 2006, National assessment of shoreline change part 3-Historical shoreline change and associated coastal land loss along sandy shorelines of the California coast: U.S. Geological Survey Open-File Report 2006-1219, 72 p., accessed April 5, 2011, at http://pubs.usgs.gov/of/2006/1219/.

Heck, R.G., 1998, Santa Barbara Channel regional formline map, top Monterey Formation, in Kunitomi, D.S., Hopps, T.E., and Galloway, J.M., eds., Structure and petroleum geology, Santa Barbara Channel, California: American Association of Petroleum Geologists, Pacific Section, Miscellaneous Publication 46, 1 plate.

Hornafius, J.S., Luyendyk, B.P., Terres, R.R., and Kamerling, M.J., 1986, Timing and extent of Neogene rotation in the western Transverse Ranges, California: Geological Society of America Bulletin, v. 97, p. 1,476-1,487.

Huftile, G.J., and Yeats, R.S., 1995, Convergence rates across a displacement transfer zone in the western Transverse Ranges, Ventura basin, California: Journal of Geophysical Research, v. 100, p. $2,043-2,067$.

Jennings, C.W., and Bryant, W.A., 2010, Fault activity map of California: California Geological Survey Geologic Data Map no. 6, scale 1:750,000.

Keough, M.J., and Downes, B.J., 1982, Recruitment of marine invertebrates-The role of active larval choices and early mortality: Oecologia, v. 54, 348-352.

Kern, J.P., 1977, Origin and history of upper Pleistocene marine terraces, San Diego, California: Geological Society of America Bulletin, v. 88, p. 1,553-1,566.

Kostic, S., Sequeiros, O., Spinewine, B., and Parker, G., 2010, Cyclic steps-A phenomenon of supercritical shallow flow from the high mountains to the bottom of the ocean: Journal of Hydroenvironment Research, v. 3, p. 167-172.

Krigsman, L.M., Yoklavich, M.M., Dick, E.J., and Cochrane, G.R., 2012, Models and maps_-Predicting the distribution of corals and other benthic macro-invertebrates in shelf habitats: Ecosphere, v. 3(1), article 3, 16 p., doi:10.1890/ES11-00295.1.

Kvitek, R., 2007, California State University, Monterey Bay, Seafloor Mapping Lab Data Library: California State University, Monterey Bay, Seafloor Mapping Lab database, accessed May 12, 2011, at http://seafloor.csumb.edu/SFMLwebDATA.htm.

Kvitek, R., Bretz, C., Cochrane, G.R., and Greene, H.G., 2006, Final report, Statewide Marine Mapping Planning Workshop, December 12-13, 2005, Seaside, Calif.: California State University, Monterey Bay, 108 p., accessed April 5, 2011, at http://euclase.csumb.edu/DATA_DOWNLOAD/Strategic MapgWrkshp05/MappingWorkshop12_12-13/Final_Report/CA\%20Habitat\%20Mapping\%20Rpt.pdf.

Lambeck, K., and Chappell, J., 2001, Sea level change through the last glacial cycle: Science, v. 292, p. 679-686, doi:10.1126/science.1059549.

Lambeck, K., Yokoyama, Y., and Purcell, T., 2002, Into and out of the Last Glacial Maximum-Sealevel change during Oxygen Isotope Stages 3 and 2: Quaternary Science Reviews, v. 21, p. 343-360. 
Larson, K.M., and Webb, F.H., 1992, Deformation in the Santa Barbara Channel from GPS measurements 1987-1991: Geophysical News Letters, v. 19, p. 1,491-1,494.

Lee, H.J., and Normark, W.R., eds., 2009, Earth science in the urban ocean-The Southern California Continental Borderland: Geological Society of America Special Paper 454, 481 p.

Lee, W.H.K., and Vedder, J.G., 1973, Recent earthquake activity in the Santa Barbara Channel region: Bulletin of the Seismological Society of America, v. 63, p. 1,757-1,773.

Luyendyk, B.P., Kamerling, M.J., and Terres, R.R., 1980, Geometric model for Neogene crustal rotations in southern California: Geological Society of America Bulletin, v. 91, p. 211-217.

Madden, C.J., Goodin, K.L., Allee, R., Finkbeiner, M., and Bamford, D.E., 2008, Draft Coastal and Marine Ecological Classification Standard: National Oceanic and Atmospheric Administration (NOAA) and NatureServe, v. III, 77 p.

Meigs, A., Brozovic, N., and Johnson, M.L., 1999, Steady, balanced rates of uplift and erosion of the Santa Monica Mountains, California: Basin Research, v. 11, p. 59-73.

Minor, S.A., Kellogg, K.S., Stanley, R.G., Gurrola, L.D., Keller, E.A., and Brandt, T.R., 2009, Geologic map of the Santa Barbara coastal plain area, Santa Barbara County, California: U.S. Geological Survey Scientific Investigations Map 3001, scale 1:25,000, 1 sheet, pamphlet 38 p., available at http://pubs.usgs.gov/sim/3001/.

Mitchum, R.M., Jr., Vail, P.R., and Sangree, J.B., 1977, Seismic stratigraphy and global changes of sea level, part 6-Stratigraphic interpretation of seismic reflection patterns in depositional sequences, in Payton, C.E., ed., Seismic stratigraphy - applications to hydrocarbon exploration: Tulsa, Okla., American Association of Petroleum Geologists, p. 117-133.

Murray, A.B., and Theiler, 2004, A new hypothesis and exploratory model for the formation of largescale inner-shelf sediment sorting and "rippled scour depressions": Continental Shelf Research, v. 24, no. 3, p. 295-315.

National Oceanic and Atmospheric Administration, 2011, Coastal ifSAR: Digital Coast, NOAA Coastal Services Center database, accessed April 5, 2011, at http://www.csc.noaa.gov/digitalcoast/.

Nicholson, C., Sorlien, C., Atwater, T., Crowell, J.C., and Luyendyk, B.P., 1994, Microplate capture, rotation of the western Transverse Ranges, and initiation of the San Andreas transform as a low-angle fault system: Geology, v. 22, p. 491-495.

Normark, W.R., Piper, D.J.W., Romans, B.W., Covault, J.A., Dartnell, P., and Sliter, R.W., 2009, Submarine canyon and fan systems of the California Continental Borderland, in Lee, H.J., and Normark, W.R., eds., Earth science in the urban ocean-The Southern California Continental Borderland: Geological Society of America Special Paper 454, p. 141-168.

O'Reilly, W.C., and Guza, R.T., 1993, A comparison of spectral wave models in the Southern California Bight: Coastal Engineering, v. 19, p. 263-282, doi:10.1016/0378-3839(93)90032-4.

Peltier, W.R., 2005, On the hemispheric origins of meltwater pulse 1a: Quaternary Science Reviews, v. 24 , p. $1,655-1,671$.

Petersen, M.D., Frankel, A.D., Harmsen, S.C., Mueller, C.S., Haller, K.M., Wheeler, R.L., Wesson, R.L., Zeng, Y., Boyd, O.S., Perkins, D.M., Luco, N., Field, E.H., Wills, C.J., and Rukstales, K.S., 2008, Documentation for the 2008 update of the United States National Seismic Hazard Maps: U.S. Geological Survey Open-File Report 2008-1128, 61 p., accessed April 5, 2011, at http://pubs.usgs.gov/of/2008/1128/.

Piper, D.J.W., Hiscott, R.N., and Normark, W.R., 1999, Outcrop-scale acoustic facies analysis and latest Quaternary development of Hueneme and Mugu submarine fans, offshore California: Sedimentology, v. 46, p. 47-78, doi:10.1111/j.1365-3091.1999.00203.x. 
Redin, T., and Kamerling, M.J., 2004, Santa Barbara Channel structure and correlation sections: American Association of Petroleum Geologists, Pacific Section, Publication CS 32, 1 sheet.

Reid, J.A., Reid, J.M., Jenkins, C.J., Zimmerman, M., Williams, S.J., and Field, M.E., 2006, usSEABED_Pacific Coast (California, Oregon, Washington) offshore surficial-sediment data release: U.S. Geological Survey Data Series 182, available at http://pubs.usgs.gov/ds/2006/182/.

Romans, B.W., Normark, W.R., McGann, M.M., Covault, J.A., and Graham, S.A., 2009, Coarse-grained sediment delivery and distribution in the Holocene Santa Monica Basin, California-Implications for evaluating source-to-sink flux at millennial time scales: Geological Society of America Bulletin, v. 121, p. 1,394-1,408.

Shaw, J.H., and Suppe, J., 1994, Active faulting and growth folding in the eastern Santa Barbara Channel, California: Geological Society of America Bulletin, v. 106, p. 607-626.

Slater, R.A., Gorsline, D.S., Kolpack, R.L., and Shiller, G.I., 2002, Post-glacial sediments of the California shelf from Cape San Martin to the US-Mexico border: Quaternary International, v. 92, p. 45-61.

Sliter, R.W., Triezenberg, P.J., Hart, P.E., Draut, A.E., Normark, W.R., and Conrad, J.E., 2008, Highresolution chirp and mini-sparker seismic reflection data from the southern California continental shelf - Gaviota to Mugu Canyon: U.S. Geological Survey Open-File Report 2008-1246, accessed April 5, 2011, at http://pubs.usgs.gov/of/2008/1246/.

Sommerfield, C.R., Lee, H.J., and Normark, W.R., 2009, Postglacial sedimentary record of the southern California continental shelf and slope, Point Conception to Dana Point, in Lee, H.J., and Normark, W.R., eds., Earth science in the urban ocean-The Southern California Continental Borderland: Geological Society of America Special Paper 454, p. 89-116.

Sorlien, C.C., Gratier, J.P., Luyendyk, B.P., Hornafius, J.S., and Hopps, T.E., 2000, Map restoration of folded and faulted late Cenozoic strata across the Oak Ridge fault, onshore and offshore Ventura basin, California: Geological Society of America Bulletin, v. 112, p. 1,080-1,090.

Southern California Earthquake Data Center, 2010, Southern California Earthquake Catalog: Southern California Earthquake Data Center database, accessed April 5, 2011, at http://www.data.scec.org/eqcatalogs/index.html.

Sylvester, A.G., 2001, Catalog of Santa Barbara earthquakes - 1800 to 1960: University of California, Santa Barbara, database, accessed April 5, 2011, at http://projects.crustal.ucsb.edu/sb_eqs/ SBEQCatlog/SBEQCATINTRO.html.

Sylvester, A.G., Smith, S.S., and Scholz, C.H., 1970, Earthquake swarm in the Santa Barbara Channel, California, 1968: Bulletin of the Seismological Society of America, v. 60, p. 1,047-1,060.

Tissot, B.N., Yoklavich, M.M., Love, M.S., York, K., and Amend, M., 2006, Benthic invertebrates that form habitat on deep banks off southern California, with special reference to deep sea coral: Fishery Bulletin, v. 104, p. 167-181.

U.S. Geological Survey, 2009, National Archive of Marine Seismic Surveys: U.S. Geological Survey database, accessed April 5, 2011, at http://walrus.wr.usgs.gov/NAMSS/.

Warrick, J.A., and Farnsworth, K.L., 2009a, Sources of sediment to the coastal waters of the Southern California Bight, in Lee, H.J., and Normark, W.R., eds., Earth science in the urban ocean-The Southern California Continental Borderland: Geological Society of America Special Paper 454, p. 3952.

Warrick, J.A., and Farnsworth, K.L., 2009b, Dispersal of river sediment in the southern California Bight, in Lee, H.J., and Normark, W.R., eds., Earth science in the urban ocean-The Southern California Continental Borderland: Geological Society of America Special Paper 454, p. 53-67. 
Weber, K.M., List, J.H., and Morgan, K.L., 2005, An operational Mean High Water datum for determination of shoreline position from topographic lidar data: U.S. Geological Survey Open-File Report 2005-1027, accessed April 5, 2011, at http://pubs.usgs.gov/of/2005/1027/.

Wiberg, P.L., Drake, D.E., Harris, C.K., and Noble, M.A., 2002, Sediment transport on the Palos Verdes shelf over seasonal to decadal time scales: Continental Shelf Research, v. 22, p. 987-1,004, doi:10.1016/S0278-4343(01)00116-9.

Wong, F.L., Phillips, E.L., Johnson, S.Y, and Sliter, R.W., 2012, Modeling of depth to base of Last Glacial Maximum and seafloor sediment thickness for the California State Waters Map Series, eastern Santa Barbara Channel, California: U.S. Geological Survey Open-File Report 2012-1161, 16 p., available at http://pubs.usgs.gov/of/2012/1161/.

$\mathrm{Xu}$, J.P., and Noble, M.A., 2009, Variability of the southern California wave climate and implications for sediment transport, in Lee, H.J., and Normark, W.R., eds., Earth science in the urban ocean-The Southern California Continental Borderland: Geological Society of America Special Paper 454, p. 171-192.

Xu, J.P., Swarzenski, P.W., Noble, M.A., and Li, A.C., 2010, Event-driven sediment flux in Hueneme and Mugu submarine canyons, southern California: Marine Geology, v. 269, p. 74-88.

Yeats, R.S., and Huftile, G.J., 1995, The Oak Ridge fault system and the 1994 Northridge earthquake: Nature, v. 373, p. 418-420.

Yeats, R.S., Huftile, G.J., and Grigsby, F.B., 1988, Oak Ridge fault, Ventura fold belt, and the Sisar decollement, Ventura basin, California: Geology, v. 16, p. 1,112-1,116.

Zeverbergen, L.W., and Thorne, C.R., 1987, Quantitative analysis of land surface topography: Earth Surface Processes and Landforms, v. 12, p. 47-56. 